\title{
Epigenetics of Stress, Addiction, and Resilience: Therapeutic Implications
}

\author{
Jean Lud Cadet
}

Received: 20 October 2014 / Accepted: 30 November 2014 / Published online: 11 December 2014

(C) The Author(s) 2014. This article is published with open access at Springerlink.com

\begin{abstract}
Substance use disorders (SUDs) are highly prevalent. SUDs involve vicious cycles of binges followed by occasional periods of abstinence with recurrent relapses despite treatment and adverse medical and psychosocial consequences. There is convincing evidence that early and adult stressful life events are risks factors for the development of addiction and serve as cues that trigger relapses. Nevertheless, the fact that not all individuals who face traumatic events develop addiction to licit or illicit drugs suggests the existence of individual and/or familial resilient factors that protect these mentally healthy individuals. Here, I give a brief overview of the epigenetic bases of responses to stressful events and of epigenetic changes associated with the administration of drugs of abuse. I also discuss the psychobiology of resilience and alterations in epigenetic markers that have been observed in models of resilience. Finally, I suggest the possibility that treatment of addiction should involve cognitive and pharmacological approaches that enhance resilience in at risk individuals. Similar approaches should also be used with patients who have already succumbed to the nefarious effects of addictive substances.
\end{abstract}

Keywords Alcohol · Cocaine - DNA methylation ·

Heroin · Histone acetylation · Methamphetamine .

Nicotine

$\begin{array}{ll}\text { Abbreviations } \\ \text { BDNF } & \text { Brain-derived neurotrophic factor } \\ \text { BLA } & \text { Basolateral nucleus of the amygdala } \\ \text { CREB } & \begin{array}{l}\text { Cyclic AMP-responsive element- } \\ \text { binding protein }\end{array} \\ \text { CBP } & \text { CREB-binding protein }\end{array}$

J. L. Cadet $(\bowtie)$

Molecular Neuropsychiatry Research Branch, DHHS/NIH/NIDA

Intramural Research Program, National Institutes of Health, 251

Bayview Boulevard, Baltimore, MD 21224, USA

e-mail: jcadet@intra.nida.nih.gov

$\begin{array}{ll}\text { CeA } & \text { Central nucleus of the amygdala } \\ \text { CPP } & \text { Conditioned place preference } \\ \text { CREB } & \text { Cyclic AMP response element binding } \\ \text { DNMT } & \text { DNA methyltransferases } \\ \text { GDNF } & \text { Glial cell-derived neurotrophic factor } \\ \text { GCN5 } & \text { General control non-repressible 5 } \\ \text { GNAT } & \text { GCN5-related N-acetyltransferase } \\ \text { H3K14Ac } & \text { Histone H3 acetylated at lysine 14 } \\ \text { H3K9Ac } & \text { Histone H3 acetylated at lysine 9 } \\ \text { H3K18Ac } & \text { Histone H3 acetylated at lysine 18 } \\ \text { H3K4me2/3 } & \text { Methylation of histone H3 at lysine 4 } \\ \text { HATs } & \text { Histone acetyltransferases } \\ \text { HDACs } & \text { Histone deacetylases } \\ \text { HPA } & \text { Hypothalamic-pituitary-adrenal } \\ \text { HR } & \text { High responders } \\ \text { LC } & \text { Locus coeruleus } \\ \text { LR } & \text { Low responders } \\ \text { KMTs } & \text { Histone lysine methyltransferases } \\ \text { KDMTs } & \text { Lysine demethylases } \\ \text { MeA } & \text { Medial nucleus of the amygdala } \\ \text { MeCP2 } & \text { Methyl-CpG binding protein 2 } \\ \text { MYST } & \text { MOZ YBF2, SAS2, and TIP60 } \\ \text { NAc } & \text { Nucleus accumbens } \\ \text { NAD } & \text { Nicotinamide adenine dinucleotide } \\ \text { NGF1A } & \text { Nerve growth factor 1A } \\ \text { NR3C1 } & \text { Neuron-specific glucocorticoid receptor } \\ \text { PCAP } & \text { p300 CBP/p300-associated protein } \\ \text { SIRT } & \text { Sirtuin } \\ \text { SUDs } & \text { Substance use disorders } \\ \text { TET } & \text { Ten-eleven translocation } \\ & \end{array}$

\section{Introduction}

Early stressful life events are important risk factors for the development of neuropsychiatric disorders that include 
affective disorders and addiction to food and illicit substances [1-7]. These traumatic events are associated with significant changes in cognitive, neurotransmitter, and neuroendocrine systems in humans and animal models [8-11]. Of interest is the fact that early stress events can cause significant changes in brain structure and function [12, 13]. Although stressassociated biochemical and structural alterations might constitute important subsets of general pathobiological substrates of psychiatric disorders, more experiments are needed to develop a theoretical framework that may have stronger translational impact on the lives of patients who suffer from substance use disorders (SUDs). SUDs are chronic neuropsychiatric disorders that are characterized by a compulsion to use licit or illicit substances, loss of control over drug use, and increased use despite adverse medical and psychological consequences $[14,15]$. Some patients who are addicted to psychostimulants including cocaine and methamphetamine suffer from cognitive decrements that might impact their activities of daily living [16-18]. Given the fact that overwhelming stressful events can also be associated with some cognitive deficits $[19,20]$, it is not farfetched to suggest that repeated life events in addicted individuals might compound the adverse consequences of their illicit drugs of choice.

It is, nevertheless, important to note, at this juncture, that not all responses to stress are maladaptive since some of these responses might constitute resilient attempts to protect the individual against overwhelming odds $[4,13]$ that include living in deprived neighborhoods and parental deprivation [3, 21-23]. Indeed, evidence has accumulated to indicate that not all individuals develop maladaptive behaviors or psychiatric disorders despite living in dire conditions that include ethnic and social disparities [24-26]. In what follows, I will first try to draw comparisons between the epigenetic substrates of stress and addiction. I also provide a brief synopsis of epigenetic modifications observed in some models of resilience. Finally, I suggest that a better therapeutic handle of SUDs may be provided by promoting behaviors associated with resilience and by using, concomitantly, pharmacological interventions that trigger epigenetic changes identified in models of resilience.

\section{Brief Overview of Epigenetic Mechanisms}

Epigenetics is defined as the investigation of heritable changes in gene transcription and/or phenotypic alterations that are not secondary to changes in DNA sequences [27]. This definition can be expanded to include meiotically and mitotically inherited alterations in gene expression that are not DNAencoded [28-30]. The two most commonly studied epigenetic alterations are modifications of histones present in chromatin [31] and DNA methylation [32]. Chromatin represents the structural and functional organization of the eukaryotic genome $[33,34]$ and contains DNA, RNA, and several protein components [34]. The basic repeating unit of chromatin is the nucleosome that consists of $146 \mathrm{bp}$ of DNA wrapped around four core histones, $\mathrm{H} 2 \mathrm{~A}, \mathrm{H} 2 \mathrm{~B}, \mathrm{H} 3$, and $\mathrm{H} 4$, which form an octomer (two of each core histone) [35]. Histone tails contain amino acid residues that can be reversely modified by histone acetyltransferases (HATs), histone deacetylases (HDACs), histone lysine methyltransferases (KMTs), and kinases, among others [36-38].

There are several classes of HATs, HDACs, and KMTs. The HAT families include cyclic AMP-responsive element binding (CREB)-binding protein (CBP)/p300, GNAT (general control non-repressible 5 (GCN5)-related N-acetyltransferases), and MYST named after its founder proteins [MOZ (also called MYST3, monocytic leukemia zinc-finger protein), YBF2, SAS2 (something about silencing 2), and TIP60 (60 kDa trans-acting regulatory protein of HIV-type 1 (tat)interaction proteins)] subclasses $[39,40]$. The GNAT HATs include GCN5 and CBP/p300-associated protein (PCAP). HDACs are subdivided into four classes according to sequence similarities [36]. These include Class I (HDAC1, HDAC2, HDAC3, HDAC8), Class II (HDAC4, HDAC5, HDAC6, HDAC7, HDAC9, HDAC10), Class III (sirtuins 1-7), and Class IV (HDAC11) HDACs [36, 41]. Class I, II, and VI HDACs are referred to as "classical" HDACs and are $\mathrm{Zn}^{2+}$-dependent enzymes [42], whereas the sirtuins require nicotinamide adenine dinucleotide (NAD)+ as a cofactor [43]. There are also several classes of KMTs that are involved in mono-, di-, and trimethylation of specific lysine residues on histones [44]. It needs to be kept in mind that methylation of histone $\mathrm{H} 3 \mathrm{~K} 4$ is generally associated with increased transcriptional activity [45] whereas methylation of $\mathrm{H} 3 \mathrm{~K} 9$ and $\mathrm{H} 3 \mathrm{~K} 27$ is associated with repression of gene expression [44, 46]. Moreover, several classes of lysine demethylases (KDMTs) counteract the effects of the KMTs [47]. Several HATs, HDACs, KMTs, and KDMTs are thought to play integral roles in the development of pathological states in both humans and animals $[48,49,46]$.

DNA methylation and hydroxymethylation are represented by covalent modifications at the 5-position of cytosine to form 5-methylcytosine and 5-hydroxymethylcytosine, respectively [50-52]. DNA methylation is mediated by the de novo DNA methyltransferases, DNMT3A and DNMT3B, and by the maintenance methyltransferase, DNMT1 [52]. In contrast, ten-eleven translocation (TET1, TET2, and TET3) enzymes mediate active DNA demethylation [53]. These epigenetic enzymes are located in the brain and have been reported to play important roles in neurodevelopment, learning and memory, and in some neurologic and psychiatric disorders [54-57]. Several recent papers have also indicated a role for epigenetic modifications in the molecular processes that lead to addiction to psychostimulants including cocaine and methamphetamine [58-62]. These authors have also suggested that an approach 
that involves blocking the effects of the drugs on epigenetic markers might be beneficial to patients. In what follows, I suggest that any such approach will need to take into consideration environmental factors that might have influenced drug-induced epigenetic alterations in the brains of these patients.

\section{Epigenetic Bases of Responses to Stressful Events}

Studies of environmental stress on epigenetic markers have documented unfavorable modifications that impact gene transcription in the brain and neuroendocrine systems [63-65]. Subsequent translational changes may in fact be the determining factors of the organism's responses to both psychological and physical stresses $[66,67]$. In the case of mild to moderate stresses, various species are able to cope by inducing general and/or stress-specific responses [68-70]. In the case of overwhelming stress, there is convincing evidence of significant stress-induced damage to the brain $[13,71]$. During the past few years, several groups of investigators have reported that both acute and chronic stresses can impact the epigenome [72-75]. For example, a single immobilization stress alters hippocampal brain-derived neurotrophic factor (BDNF) gene expression and histone acetylation at BDNF gene promoters [73]. Berton et al. [76] also reported that chronic social defeat to repeated aggression caused increased BDNF in the brain. Importantly, BDNF knockdown in the nucleus accumbens (NAc) blocked the transcriptional effects of aggressive acts. Krishnan et al. [77] also showed that only mice sensitive to stress showed increased BDNF levels. Moreover, Roth et al. [78] have reported that a psychosocial stress regimen produced increased BDNF DNA methylation at exon IV and decreased mRNA expression in the dorsal hippocampus of adult rats.

Interestingly, hypersensitivity to stress was found to be due to loss of HDAC5, a class IIA HDAC [79]. In addition, chronic defeated mice show decreased expression of HDAC2, a member of class I HDACs, in the NAc [80]. There were also decreased levels of histone H3 acetylated at lysine 14 (H3K14Ac) in mice euthanized at $1 \mathrm{~h}$ after the final stress episode whereas there was increased H3K14Ac abundance at $24 \mathrm{~h}$ and 10 days after stress [80]. This study shows the time dependence of the effects of stress and withdrawal from stressful events. Mice susceptible to stress also show decreased expression of G9a (KMT1C) [81], an enzyme responsible for H3K9 methylation [82]. There was an associated decrease in the levels of $\mathrm{H} 3 \mathrm{~K} 9$ methylation in the NAc of these mice. A causal relationship between G9a and stress sensitivity was demonstrated by showing that increasing its expression in the NAc antagonized the effects of stress [82].

Other investigators have also assessed the role of epigenetic mechanisms in high responder (HR) and low responder
(LR) rats [83]. HR rats show high locomotor activity while LR rats show low locomotor responses when exposed to a novel environment [84, 85]. The HR and LR dichotomy is a known predictor of behavioral and biochemical responses to addictive substances including cocaine and the amphetamines [86, 84, 87, 85]. The HR and LR rats were also reported to show differential epigenetic responses to stress, with HR rats exhibiting decreased $\mathrm{H} 3 \mathrm{~K} 14$ acetylation but the LR rats experiencing increased $\mathrm{H} 3 \mathrm{~K} 14$ acetylation [83]. These results indicate that these rats might show differential transcriptional responses to stress because acetylation of histones is an important regulator of gene expression [88]. It needs also to be pointed out that H3K14 acetylation is mediated, in part, by CBP [89], a histone acetyltransferase that plays an important role in the regulation of psychostimulant-induced behaviors and gene expression in the brain [90,91].

In addition to stress encountered during adulthood, early life stresses can negatively impact the brain and behavioral outputs during both adolescence and adulthood [92]. These stresses include paternal and maternal deprivation [63, 93, 94]. Several investigators have also reported on the complex epigenetic effects of these types of stressors [95, 96]. In humans, prenatal exposure of maternal depression was associated with increased methylation of the neuron-specific glucocorticoid receptor (NR3C1) measured in genomic DNA obtained from cord blood of newborns [97]. Interestingly, McGowan et al. also reported decreased NR3C1 mRNA expression and increased DNA methylation at an NR3C1 promoter in the postmortem hippocampi of suicide victims who had a history of child abuse [98]. Moreover, Perroud et al. found changes in NR3C1 expression in adults with a history of child abuse, changes that were linked to the severity of the traumatic events [99]. These findings were further supported by the report that parental loss and childhood mistreatment were associated with increased $\mathrm{NR} 3 \mathrm{C} 1$ promoter methylation in DNA obtained for leukocytes [100]. Interestingly, the adult rodent offsprings of high compared to low maternal care mothers show differential epigenetic changes in promoter regions and exons [95]. The epigenetic changes include decreased H3K9Ac enrichment, increased DNA methylation, and decreased expression of several genes in the low maternal care group [95]. Rats subjected to maternal deprivation for $2-$ 13 days showed hypothalamic-pituitary-adrenal (HPA) axis hypersensitivity, increased corticotropin-releasing hormone (CRH) transcription in the paraventricular nucleus, and decreased DNA methylation at a CRE site in the $\mathrm{CRH}$ promoter [63]. More recently, convincing evidence has shown that offsprings of males that were subjected to post-traumatic stress showed impaired recognition memory, altered expression of genes involved in synaptic transmission and CREB phosphorylation pathways in the hippocampus, as well as abnormal hippocampal electrophysiological responses [101]. Therefore, when taken together, the accumulated literature 
indicates that early stressful events including maternal and paternal deprivation can cause long-lasting epigenetic changes that are measurable in adult mammals. It is, nevertheless, important to keep in mind that stressful events can cause epigenetically regulated biochemical, molecular, and structural changes in the brain at any period throughout an individual's lifespan [102].

\section{Epigenetic Changes Associated with the Administration of Drugs of Abuse}

Humans who suffer from SUDs constitute a group of individuals whose life spans are characterized by repeated stressful life events [103-105]. Indeed, traumatic events are risk factors for developing addiction to either licit or illicit drugs [2, 3]. These reports suggest that epigenetic alterations caused by stressful events might have rendered these individuals more susceptible to drug-induced neuroplastic changes that form the substrates of addictive diseases. In what follows, I provide a brief overview of some papers that have addressed the issue of drug-induced epigenetic changes in the mammalian brain. These drugs include, in alphabetical order, alcohol, cocaine, methamphetamine, nicotine, and opiates.

Alcohol The effects of alcohol on gene expression in the brain are well documented [106, 107]. More recently, several groups of investigators have begun to investigate potential epigenetic modifications that are secondary to alcohol exposure using various animal models [108, 109]. For example, Pandey et al. [110] had reported that an acute injection of alcohol caused decreased HDAC activity in the rat amygdala. They also found increased acetylation of histones $\mathrm{H} 3$ and H4 in the central (CeA) and medial (MeA) nuclei but not in the basolateral (BLA) nucleus of the amygdala. In contrast, alcohol withdrawal was associated with decreased histones $\mathrm{H} 3$ and $\mathrm{H} 4$ acetylation in the $\mathrm{CeA}$ and MeA. Moreover, alcohol withdrawal produced decreased expression of the HAT, CBP, in these brain amygdaloid nuclei. HDAC activity was, however, increased in the amygdala of similarly treated rats. D'Addario et al. [111] recently reported that binge administration of alcohol produced changes in the expression of prodynorphin and pronociceptin genes in the rat amygdala. The authors also reported increased acetylation of histone 3 at lysine 9 (H3K9Ac) but decreased abundance of $\mathrm{H} 3$ trimethylated at lysine 27 (H3K27me3) at the promoters of these two genes in animals treated with alcohol for 1 day. These histone modifications were also associated with increased prodynorphin and pronociceptin mRNA expression. Animals treated for 5 days showed only increased H3K9Ac at the pronociceptin promoter. Qiang et al. [112] also reported that withdrawal from chronic intermittent administration of alcohol increased H3K9Ac abundance at the glutamate receptor, NR2B. They also found decreased abundance of the methyltransferases, G9a and Suv39h1 (KMT1A), and of HDAC1-3 on the NR4B promoter region. Using a global chromatin immunoprecipitation (ChIP) technique, Zhou et al. [113] reported that there were significant changes in $\mathrm{H} 3 \mathrm{~K} 4 \mathrm{me} 3$ abundance in a large number of genes in the hippocampus of alcoholics. However, these changes were not directly related to changes in the expression of any of these genes. A similar study also found marked changes in gene expression in the superior frontal cortex (CTX) as well as in the CeA and BLA of the amygdala [114]. Among these genes were mixed lineage leukemia (MLL also called KMT2A), MLL4 (KMT2B), and SET domain containing 1A (SETD1A also called KMT2F) that are involved in histone H3K4 trimethylation. The authors also observed increased H3K4me3 abundance at the promoters of BCL2L1 (B cell lymphoma 2-like1) and UBE1 (ubiquitin-like activating enzyme-1) whose mRNA levels are also increased in the brains of the alcoholic patients. In addition to alcohol-induced changes in histone markers, alterations in DNA methylation in the brains of alcohol abusing individuals have also been reported [115]. These authors reported that alcoholics showed higher methylation peaks than controls. Some of these genes of interest included HIST2H2AC and HIST1H4E, supporting the notion that alcohol abuse might be associated with altered histone modifications, as discussed above. In contrast, Ponomarev et al. [114] reported hypomethylation at DNA sequences called long terminal repeat (LTR)-containing retroposons. Taken together, these investigations identify multiple epigenetic alterations associated with alcohol administration.

Cocaine Cocaine causes substantial changes in gene expression in the brain [116-118]. However, the epigenetic bases of these transcriptional alterations needed to be clarified. Several groups of investigators have now published papers on the effects of cocaine on epigenetic markers in several brain regions [119]. These studies have included both acute and chronic effects of the drug. For example, Kumar et al. [120] reported that a single injection of cocaine increased c-fos mRNA levels and increased histone $\mathrm{H} 4$ acetylation at the cfos promoter. In contrast, chronic cocaine did not induce c-fos mRNA nor histone hyperacetylation. Moreover, the authors detected increased histone $\mathrm{H} 3$ acetylation at the BDNF promoter and increased BDNF mRNA levels. Subsequently, Levine et al. [90] documented a role for the acetyltransferases, CBP, which was found to control the effects of cocaine via acetylation of histones at the fosB promoter. Malvaez et al. [91] have also identified a role for CBP and histone acetylation in cocaine-induced behaviors. Moreover, Romieu et al. [121] showed that HDAC inhibitors could decrease cocaine self-administration, documenting roles for histone acetylation in cocaine-induced behaviors and molecular effects. This 
suggestion is supported by the report that cocaine selfadministration caused increased HDAC2 and HDAC11 expression [122]. Cocaine self-administration also caused decreased HDAC5 accumulation in the nucleus, suggesting that this class IIA HDAC may, in part, regulate some of cocaineinduced molecular effects in the brain. In addition to HDAC5 [122, 123], other HDACs including HDAC1 [124], HDAC3 [125], and HDAC4 [126] have also been implicated in cocaine-induced behavioral changes. The class III HDACs including SIRT1 and SIRT2 also participate in the actions of cocaine in the brain $[127,128]$.

Other investigators have also documented long-term changes in gene expression after cocaine self-administration, with some of these changes being related to differential alterations in histone $\mathrm{H} 3$ acetylation [118]. One gene that is upregulated by chronic cocaine is CaMKIIalpha [126]. CaMKIIalpha is a very important kinase in the adult brain and plays important roles in synaptic plasticity and in mechanisms involved in learning and memory [129]. It is also of interest that increased BDNF expression observed after cocaine withdrawal [130] also involves increased histone acetylation at the BDNF exon-I promoter [131]. Importantly, some of the epigenetic effects of cocaine are dependent on stimulation of DA D1-dependent signaling pathways [132]. In addition to histone acetylation, cocaine-induced neuroadaptations appear to be also dependent on histone methylation because repeated exposure to cocaine produced decreased global levels of H3K9me2 and decreased expression of the methyltransferase, G9a, in the nucleus accumbens [133]. Interestingly, repeated injections of THC, the active ingredient of marijuana, also caused decreased $\mathrm{H} 3 \mathrm{~K} 9 \mathrm{me} 2$ but increased $\mathrm{H} 3 \mathrm{~K} 4 \mathrm{me} 3$ at sites flanking the proenkephalin transcription start site (TSS) using tissues from the shell subdivision of the rat NAc [134]. Cocaine also increased the expression of methyl-CpG binding protein $2(\mathrm{MeCP} 2)$ and produced de novo DNA methylation $[122,135]$. Moreover, exposure to cocaine increased MeCP2 phosphorylation [136, 137]. Importantly, knockdown of $\mathrm{MeCP} 2$ in the dorsal striatum was shown to decrease cocaine intake by regulating BDNF levels in that structure [138]. Furthermore, Anier et al. [139] reported that acute cocaine caused upregulation of DNMT3A and DNMT3B in the mouse NAc. Cocaine also caused hypermethylation and increased $\mathrm{MeCP} 2$ binding at the promoter of the protein phosphatase-1 catalytic subunit (PP1c) and decreased PP1c mRNA expression. The reverse was true for the effects of cocaine on the fosB promoter and fosB mRNA levels. Together, these findings suggest that cocaine can trigger epigenetic alterations that might influence, in the long term, memories associated with cocaine-related behaviors.

Methamphetamine Although methamphetamine is a highly addictive drug with a higher prevalence than cocaine abuse throughout the world, basic mechanisms associated with methamphetamine addiction have been less well studied than those of cocaine. In the past, many studies have been dedicated to toxic effects caused, in part, by allostatic load due to druginduced release of high levels of dopamine in the dorsal striatum [140]. Some studies have also focused on behavioral models such as self-administration [141] and the effects of these drugs on gene expression [142, 143]. More recently, a few groups of investigators have begun to carry experiments to elucidate potential epigenetic effects of this drug [58]. Specifically, Martin et al. [144] reported that an acute injection of methamphetamine caused decreased abundance of histone $\mathrm{H} 3$ acetylated at lysine 9 (H3K9Ac) and at lysine 18 (H3K18Ac) in the rat NAc. There was also methamphetamine-induced hyperacetylation of H4K5 and H4K8. The increased $\mathrm{H} 4$ acetylation is consistent with the results of Harkness et al. [145] who also reported that acute methamphetamine also increased $\mathrm{H} 4$ acetylation in the striatum. These results are also consistent with the report that acute methamphetamine increased the expression of several immediate early genes and that these increases were correlated with methamphetamine-induced increased binding of acetylated H4K5 on the promoters of these genes [146]. The increased histone acetylation may be the result of drug-mediated decreased HDAC1 expression since the methamphetamine injection produced decreased HDAC1 expression in nuclear sub-fractions from the NAc [144]. The possibility that the methamphetamine-induced increased $\mathrm{H} 4$ acetylation might be due to increase in CBP expression also needs to be evaluated because increased CBP expression is associated with increased histone acetylation [147]. This possibility is bolstered by the fact that methamphetamine selfadministration can regulate gene expression via CREB phosphorylation [60]. In any case, the results of the acute methamphetamine injection suggest that both HDAC1 and HDAC2 might participate in the regulation of methamphetamineinduced changes in gene expression in the brain. In the NAc, acute methamphetamine injection also causes increased expression of the mitochondrial sirtuins, SIRT3 and SIRT5, sirtuins known to play an integral part in regulating mitochondrial functions $[148,149]$. Other studies conducted by Jayanthi et al. [59] have also documented that chronic methamphetamine can cause increased expression of HDAC1, HDAC2, SIRT1, and SIRT2 in the dorsal striatum. Those authors also reported increased expression of other epigenetic proteins including MeCP2, REST, and Co-REST that are members of corepressor complexes with class I HDACs that serve to regulate gene transcription [150-152]. Methylation of histone $\mathrm{H} 3$ at lysine 4 (H3K4 me2/3) also appears to be important in methamphetamine-induced conditioned place preference (CPP) because increased methylation is associated with increased CPP whereas decreased methylation is related to decreased CPP [153].

Related to the above discussion on stress is the fact that maternal separation was found to promote greater 
methamphetamine self-administration and to enhance the effects of the drug on MeCP2 expression in the core of the nucleus accumbens [154]. These results are consistent with the possibility that methamphetamine might produce increased DNA methylation because the drug increases DNMT1 expression in the brain [59, 155]. Indeed, it was recently reported that mice that had been exposed to methamphetamine in utero showed differentially DNA methylation in their hippocampi [156]. When taken together, these results indicate that methamphetamine can also exert a multiplicity of epigenetic changes in the brain.

Nicotine The effects of nicotine on gene expression in the brain have been documented [157, 158]. Recently, there has also been a focus on identifying potential nicotine-induced epigenetic alterations [159]. For example, chronic nicotine has been reported to enhance cocaine-induced synaptic plasticity by increasing $\mathrm{H} 3 \mathrm{~K} 9$ and total $\mathrm{H} 4$ protein acetylation that was associated with increased H3K9Ac and total H4Ac binding to the FosB promoter in samples obtained from the mouse ventral striatum [160]. These nicotine-induced changes in histone acetylation were secondary to decreased HDAC activity and accompanied by increased FosB mRNA expression. Interestingly, use of the HDAC inhibitor, suberoyl ailide hydroxamine acid (SAHA), was reported to mimic the effects of nicotine on the physiological effects of cocaine. A subsequent study by the same group also found that nicotine could also enhance cocaine-induced physiological changes via HDAC inhibition [161]. Another group of investigators reported that repeated subcutaneous injections of nicotine produced increased expression of dopamine D1 receptors in the rat frontal cortex [162]. These increases were associated with increased $\mathrm{H} 4$ acetylation at the D1 receptor promoter. In addition to increased histone acetylation, others have shown that exposure to nicotine can decrease the expression of histone methyltransferases including G9a and Setblin the mouse cortex [163]. This pattern of nicotine administration also increased BDNF expression that was mediated, in part, by decreased $\mathrm{H} 3 \mathrm{~K} 9 \mathrm{me} 2$ binding to the BDNF promoter. Nicotine injections also decreased the mRNA and protein expression levels of the DNA methylation enzyme, DNMT1, in the mouse cortex and hippocampus [164]. Nicotine also produced increased cortical GAD67 mRNA expression that was accompanied by decreased levels of GAD67 promoter methylation. Together, these papers support the notion that nicotine can produce changes in gene expression via diverse epigenetic alterations.

Opiates Administration of heroin and other opiates alters the expression of genes involved in multiple molecular pathways $[116,165,166]$. A few studies have now been conducted on the role of epigenetic mechanisms in opiate-mediated behaviors. For example, heroin CPP produced dose-dependent histone $\mathrm{H} 3$ phosphoacetylation in the nucleus accumbens [167]. Morphine context-associated memory is enhanced by injections of the HDAC inhibitor, trichostatin A (TSA), directly into the BLA of the amygdala [168]. These injections led to increased H3K14 acetylation and increased BNDF expression. Other investigators have demonstrated that morphine withdrawal is associated with decreased histone H3K9 trimethylation at BDNF promoters II and III in the VTA and locus coeruleus (LC) but increased $\mathrm{H} 3 \mathrm{~K} 9 / 14$ acetylation at the BDNF promoter II only in the LC [169]. These epigenetic modifications were consistent with increased BDNF mRNA levels in morphine-withdrawn rats. Another interesting study reported that chronic morphine administration did not cause any changes in histone H3 phosphorylation [170]. However, naltrexone-induced withdrawal produced increased $\mathrm{H} 3$ phosphorylation that was mediated, in part, by ERK-dependent mechanisms in the rat NAc and the lateral septum. There was also increased H3K14 acetylation in the shell of the NAc. Chronic morphine decreased G9a expression and global levels of H3K9me2 in the mouse NAc [171]. G9a upregulation in the NAc also interferes with morphine CPP and locomotor sensitization. In comparison to control mice, morphine also caused marked changes in global $\mathrm{H} 3 \mathrm{Kme} 2$ binding in the mouse NAc, as detected by ChIP-Seq, with 8103 sites being downregulated but 5669 being upregulated. Three glutamate receptor genes (Grin2A, Grm5, and Grm8) that showed decreased $\mathrm{H} 3 \mathrm{~K} 9 \mathrm{me} 2$ binding also showed increased mRNA levels, thus implicating glutamatergic systems in opiate addiction [171]. The effects of opiates on DNA methylation have also being investigated, without there being any significant changes observed in the mouse brain after chronic intermittent heroin administration [172].

In summary, this overview of the molecular effects of various drugs of abuse suggests that these substances can produce a multitude of epigenetic modifications whether animals were injected by experimenters or were put through a self-administration paradigm. Nevertheless, the specific role of these epigenetic alterations in the development of truly addicted states remains to be elucidated further.

\section{Psychobiology of Resilience}

Resilience refers to a relative protection of an individual or family against environmental stresses to which others might be prone to succumb [173-176]. Levels of resilience have been shown to predict hopelessness that is a harbinger of future affective disorders [177, 178]. Resilience may also explain the fact that not all adolescents or adults who live in areas of deprivation based on ethnic and socioeconomic factors become addicted to either licit or illicit drugs [179-183]. There also appear to be gender differences in resilient 
outcomes, with women showing more resilience than men [184]. In humans, interactions between family characteristics, community involvement, and genetic markers may confer sensitivity to increased morbidity to a number of medical and psychiatric illnesses including SUDs [179, 180, 185]. Some of the genetic markers include polymorphism in genes that encode dopamine receptors and the serotonin transporter $[179,180,185]$, with socioeconomic status influencing the trajectory of pathologies associated with these polymorphisms [186].

In addition to potential individual genetic predilections [187], evidence has been collected in animal models that epigenetic modifications might also play a role in the development of resilient phenotypes [81, 188]. As mentioned above, resilient mice that were exposed to chronic stress do not show abnormalities in the expression of the G9a histone methyltransferase enzyme in their NAc whereas susceptible animals do [81]. Stressed animals that were susceptible to stressful events showed differential abundance of histone H3K27 methylation at several genes whereas resilient mice showed patterns that were similar to normal animals [189]. Uchida et al. [190] also published an interesting study showing that stress can produce epigenetic regulation of striatal GDNF (glial cell-derived neurotrophic factor) responses in mice that differ in their susceptibility to stress.

There is also evidence that coping/resilient mechanisms in response to stressful stimuli can be enhanced in various ways. For example, the accumulated evidence suggests that the HPA response to stressful events is influenced by maternal behaviors [191, 192]. In rodents, these responses are influenced by maternal care and are mediated by epigenetically determined changes in gene expression [193-195]. These maternal behavior-induced epigenetic changes include differences in DNA methylation and histone acetylation and binding of the transcription factor, NGFIA (nerve growth factor 1A), at the promoter of the glucocorticoid receptor [194], with some degree of reversibility through a dietary manipulation [196]. Of singular importance to the theme being promulgated here is the fact that these maternal behaviors can also influence future daughters' behaviors when they, themselves, become mothers [197, 198]. Moreover, Gonzalez et al. [199] had reported that maternal deprivation could have negative intergenerational effects on the behaviors of female rats, with other investigators reporting similar findings [200]. Furthermore, Shoji and Kato [201] have investigated the development of maternal behaviors in $\mathrm{BALC} / \mathrm{c}$ and $\mathrm{CBA} / \mathrm{Ca}$ mice that differ in parenting behaviors, with the $\mathrm{CBA} / \mathrm{Ca}$ being better mothers. The authors demonstrated that cross-fostering of BALB/c pups by $\mathrm{CBA} /$ $\mathrm{Ca}$ mothers improves the future mothering behaviors of $\mathrm{BALB} / \mathrm{c}$ females that show, when they become mothers, increased licking and grooming of their own pups. The evidence reviewed here suggests that training human mothers to provide good maternal care may have positive trans- generational effects within communities affected by socioeconomic adversities. Similar arguments can be put forward for paternal care [202, 203]. Mychasiuk et al. [202] also reported that paternal stress had negative impact on behaviors and increased DNA methylation in the hippocampus of their offsprings. In contrast, enrichment of the environment of male Long Evans rats with toys, multiple levels of exploration, and several cage mates for 28 days before mating with control female rats had positive impact on exploratory behaviors of the males' offsprings and on DNA methylation in their hippocampi and frontal cortices [203]. Enrichment of paternal environment can also have positive effects on maternal care and pup behaviors [204]. Although more research is needed to investigate the potential effects of these kinds of manipulations on future drug taking in animal models, the reviewed observations suggest that promoting resilience may impact drug self-administration in the offsprings of parents reared in enriched environments.

\section{Therapeutic Implications: Promoting Resilience Against Substance Use Disorders}

In the past two decades, there has been a heavy reliance on the potential of brain science to explain the cause, development, and clinical course of SUDs [205]. This reductionist construct has led to a large number of important basic science discoveries that have not yet significantly impacted the daily lives of patients who suffer from these recalcitrant disorders. This statement is not only true for SUDs but also for several medical and psychiatric disorders where there are obvious disparities based on ethnic and socioeconomic status [206-208]. In the case of SUDs, the almost complete theoretical reliance on the behavioral, biochemical, and epigenetic observations in animals to explain human addiction might have corrupted our efforts to develop therapeutic approaches. This is because the focus has almost solely been on potential pharmacological "magic bullets" for a quick fix of the addictions. Similar approaches to other complex neuropsychiatric illnesses have not necessarily met with greater therapeutic outcomes. In fact, this reductionist emphasis might have led to a closure of our minds to the potential for families, communities, and other sources of enrichment to enhance resilience in individuals who are at risk [209] or are already suffering from SUDs.

As stated above, not everybody subjected to gross disparities ends up with a diagnosis of SUDs. This fact implicates individual as well as family- and community-based resilient factors in protecting these individuals against drug addiction $[180,210,211]$. These observations notwithstanding, instead of pursuing an agenda that actively promotes enhancement of resilience by reinforcing identified protective factors [212-214], the focus has been mainly on identifying negative 


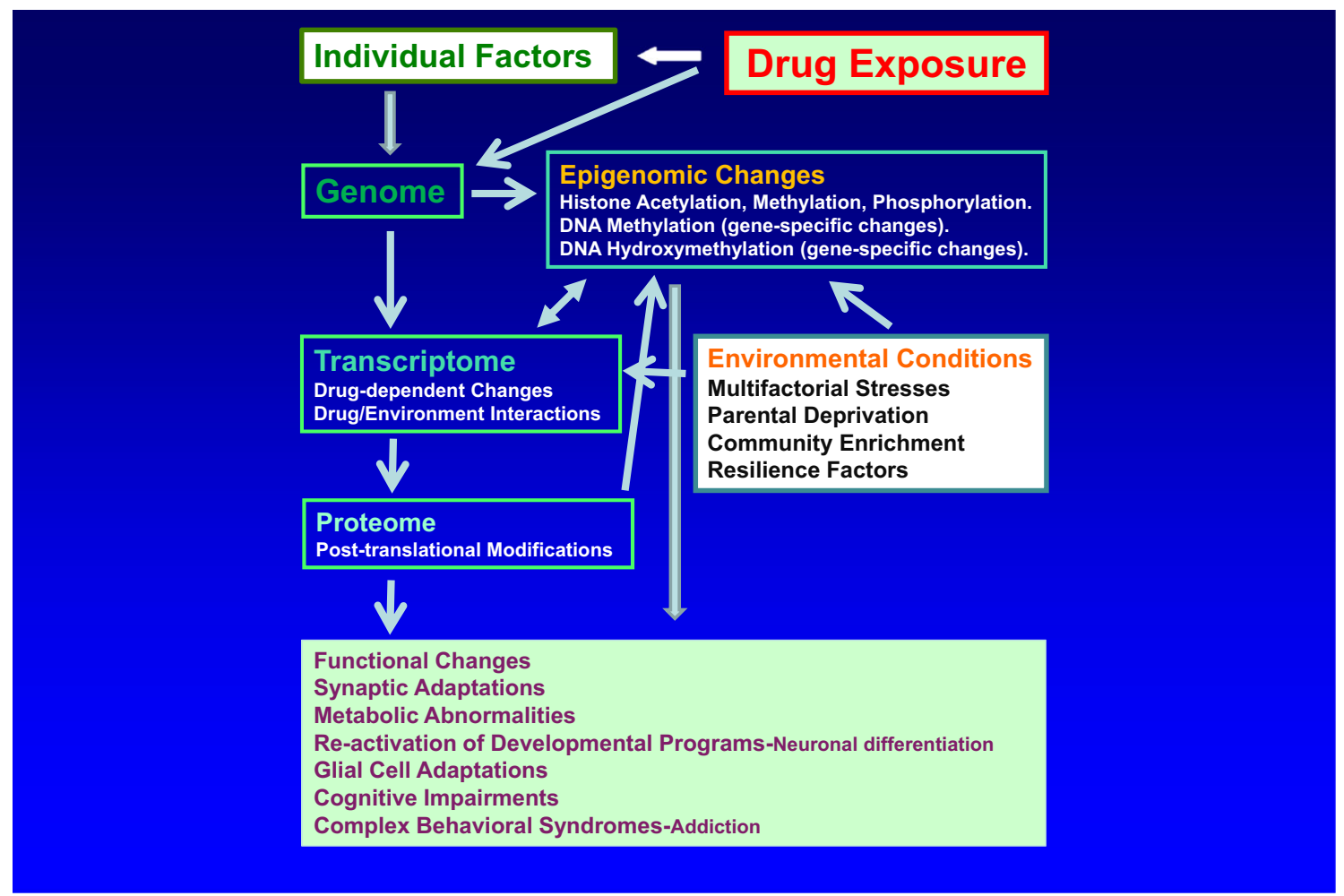

Fig. 1 Schema showing the potential interactions of drugs of abuse with an individual's genome and the impact of environmental vicissitudes on the individual's responses to these agents. The epigenetic responses to the drug will probably be dependent on the genetic background, family resilient factors, and environmental stressors that individuals face during their lifetimes. Substance use disorders (addiction) are thus viewed not as reductionist constructs but as multifactorial complex neuropsychiatric disorders, with only a few individuals actually developing those syndromes after trying various rewarding substances.
This statement suggests the need to develop more animal models that take these issues into consideration. By extension, our pharmacological treatments may thus be bound to fail because present approaches of developing therapeutic agents employ all animals that self-administer a drug in question whereas only a few percentages of humans become addicted to a licit or illicit substance. The schema also suggests the need to identify resilient factors within individuals and families that treatment personnel can shore up within addicted individuals and teach to those who are living in high-risk situations or pathological elements in these communities [215]. I suggest that a more profitable approach for our addicted patients may be to identify resilient factors such as coping styles because these characteristics have been shown to reduce vulnerability to medical and psychiatric disorders in humans $[216,217]$. There is also evidence, in animal models, that promotion of active coping can have significant neuroendocrine and epigenetic effects [218] whereas maternal deprivation can influence drug-taking behaviors [94]. In fact, an agenda that tries to identify resilient factors would have the added benefit of improving the treatment of patients who are co-morbid for SUDs and other psychiatric disorders [219].

This discussion further suggests a need for a research emphasis that attempts to identify coping styles of individuals and families that show resilience against the ravages of SUDs although they are still living in environments marred by poverty, poor access to education, or repeated discriminatory aggressive acts [220]. Once these coping styles are identified, it may be possible to enhance these behavioral patterns through active mentoring of individuals at risks, in effect, recognizing the potential prominence of social interactions in the development of phenotypic diversity within specific environments. Because the effects of life stresses [221] and resilient behaviors [203] can be transmitted across generations, these environmental interventions may have substantial positive cost/benefit ratios for our health care systems and our nations by negating the complex effects of environmental stresses on the behaviors of young children and adolescents reared in these settings. This conclusion is supported by the high co-morbidity of other psychiatric diatheses and SUDs and the fact that some of these disorders appear to share similar developmental risks and potential epigenetic substrates [222, 223].

This thesis does not negate the need for continued support of reductionist approaches that provide useful neurobiological explanations for the direct effects of drugs on the brain. It hints, however, to the added possibility of using therapeutic agents such as antidepressant drugs alone or in combination with other epigenetic agents that have been shown to promote resilience in animal models [81]. I argue, however, that these pharmacological agents may be more beneficial when used in conjunction with 
mentoring activities that promote active coping. This proposal also points to the need to develop better animal models that are more representative of human conditions [224, 225, 141, 226] since not everyone who experiments with drugs is or will become a drug addict. The development of better models will help to differentiate biochemical and epigenetic effects observed after simple drug exposure from those alterations associated with true addicted states. The need to use better animal models of addiction in molecular studies is illustrated well by recent papers that have purported to identify nicotine-induced epigenetic modifications that were proposed as supporting evidence for the idea of nicotine as a gateway agent to psychostimulant abuse [159]. I argue further that these new models would need to go beyond superficial similarities between animal responses to drugs of abuse and the complex cognitive behaviors and affective states observed in our addicted patients. As a consequence of using better models, pharmacologic agents derived from these experiments would be more specific in terms of blocking or suppressing epigenetic, transcriptional, and biochemical changes associated with sensitivity to stress and SUDs. By extension, these medications may have a greater impact on the lives of our patients. Using this line of reasoning, SUDs will need to be viewed not as being secondary solely to drug-induced biochemical and epigenetic effects but as, most likely, to be secondary to interactions of drugs with the genomes of individuals living within an environment that was permissive to the development of pathologic use of drugs (see Fig. 1 for a schematic rendering). This statement re-emphasizes the need to always bear in mind the existence of resilient factors or traits in individuals, families, and sub-communities that have shown their utilities in combating the effects of drugs in individuals, even when said individuals had experimented with addictive substances during their adolescence. I believe that this capacity to thrive against inordinate odds can be strengthened through mentored good mothering.

Acknowledgments This work was supported by funds of the Intramural Research Program of the DHHS/NIH/NIDA. The author thanks Maryann Carrigan, Christie Brannock, and Dr. Subramaniam Jayanthi for editorial help. The author also thanks two anonymous reviewers whose comments helped to improve this paper.

Conflict of interest The author declares that he has no conflict of interest.

Open Access This article is distributed under the terms of the Creative Commons Attribution License which permits any use, distribution, and reproduction in any medium, provided the original author(s) and the source are credited.

\section{References}

1. Breslau N (2002) Epidemiologic studies of trauma, posttraumatic stress disorder, and other psychiatric disorders. Can J Psychiatr 47(10):923-929
2. Enoch MA (2011) The role of early life stress as a predictor for alcohol and drug dependence. Psychopharmacol (Berl) 214(1):1731. doi:10.1007/s00213-010-1916-6

3. Kendler KS, Ohlsson H, Sundquist K, Sundquist J (2014) The causal nature of the association between neighborhood deprivation and drug abuse: a prospective national Swedish corelative control study. Psychol Med 44(12):2537-2546. doi: 10.1017/S0033291713003048

4. Luyten P, Vliegen N, Van Houdenhove B, Blatt SJ (2008) Equifinality, multifinality, and the rediscovery of the importance of early experiences: pathways from early adversity to psychiatric and (functional) somatic disorders. Psychoanal Study Child 63:27-60

5. Mason SM, Flint AJ, Roberts AL, Agnew-Blais J, Koenen KC, Rich-Edwards JW (2014) Posttraumatic stress disorder symptoms and food addiction in women by timing and type of trauma exposure. JAMA Psychiatr. doi:10.1001/jamapsychiatry.2014.1208

6. Messina N, Marinelli-Casey P, Hillhouse M, Rawson R, Hunter J, Ang A (2008) Childhood adverse events and methamphetamine use among men and women. J Psychoactive Drugs Suppl 5:399-409

7. Patchev AV, Rodrigues AJ, Sousa N, Spengler D, Almeida OF (2014) The future is now: early life events preset adult behaviour. Acta Physiol (Oxf) 210(1):46-57. doi:10.1111/apha.12140

8. Bisagno V, Cadet JL (2014) Stress, sex, and addiction: potential roles of corticotropin-releasing factor, oxytocin, and arginine-vasopressin. Behav Pharmacol 25(5-6):445-457. doi:10.1097/FBP. 0000000000000049

9. Gould F, Clarke J, Heim C, Harvey PD, Majer M, Nemeroff CB (2012) The effects of child abuse and neglect on cognitive functioning in adulthood. J Psychiatr Res 46(4):500-506. doi:10.1016/j. jpsychires.2012.01.005

10. Heim C, Young LJ, Newport DJ, Mletzko T, Miller AH, Nemeroff CB (2009) Lower CSF oxytocin concentrations in women with a history of childhood abuse. Mol Psychiatr 14(10):954-958. doi:10. 1038/mp.2008.112

11. Touma C, Bunck M, Glasl L, Nussbaumer M, Palme R, Stein H, Wolferstatter M, Zeh R, Zimbelmann M, Holsboer F, Landgraf R (2008) Mice selected for high versus low stress reactivity: a new animal model for affective disorders. Psychoneuroendocrinology 33(6):839-862. doi:10.1016/j.psyneuen.2008.03.013

12. Kaufman J, Charney D (2001) Effects of early stress on brain structure and function: implications for understanding the relationship between child maltreatment and depression. Dev Psychopathol 13(3):451-471

13. McEwen BS (2006) Protective and damaging effects of stress mediators: central role of the brain. Dialogues Clin Neurosci 8(4): 367-381

14. Cadet JL, Bisagno V (2013) The primacy of cognition in the manifestations of substance use disorders. Front Neurol 4:189. doi:10.3389/fneur.2013.00189

15. Hasin DS, O’Brien CP, Auriacombe M, Borges G, Bucholz K, Budney A, Compton WM, Crowley T, Ling W, Petry NM, Schuckit M, Grant BF (2013) DSM-5 criteria for substance use disorders: recommendations and rationale. Am J Psychiatr 170(8): 834-851. doi:10.1176/appi.ajp.2013.12060782

16. Bolla K, Ernst M, Kiehl K, Mouratidis M, Eldreth D, Contoreggi C, Matochik J, Kurian V, Cadet J, Kimes A, Funderburk F, London E (2004) Prefrontal cortical dysfunction in abstinent cocaine abusers. J Neuropsychiatry Clin Neurosci 16(4):456-464. doi:10.1176/appi. neuropsych.16.4.456

17. Bolla KI, Funderburk FR, Cadet JL (2000) Differential effects of cocaine and cocaine alcohol on neurocognitive performance. Neurol 54(12):2285-2292

18. Dean AC, Groman SM, Morales AM, London ED (2013) An evaluation of the evidence that methamphetamine abuse causes 
cognitive decline in humans. Neuropsychopharmacol 38(2):259274. doi:10.1038/npp.2012.179

19. Jackson JC, Mitchell N, Hopkins RO (2009) Cognitive functioning, mental health, and quality of life in ICU survivors: an overview. Crit Care Clin 25(3):615-628. doi:10.1016/j.ccc.2009.04.005

20. Lupien SJ, McEwen BS, Gunnar MR, Heim C (2009) Effects of stress throughout the lifespan on the brain, behaviour and cognition. Nat Rev Neurosci 10(6):434-445. doi:10.1038/nrn2639

21. Barrington WE, Stafford M, Hamer M, Beresford SA, Koepsell T, Steptoe A (2014) Neighborhood socioeconomic deprivation, perceived neighborhood factors, and cortisol responses to induced stress among healthy adults. Health Place 27:120-126. doi:10. 1016/j.healthplace.2014.02.001

22. Castro FG, Brook JS, Brook DW, Rubenstone E (2006) Paternal, perceived maternal, and youth risk factors as predictors of youth stage of substance use a longitudinal study. J Addict Dis 25(2):6575. doi: $10.1300 / J 069 v 25 n 02 \_10$

23. Solis JM, Shadur JM, Burns AR, Hussong AM (2012) Understanding the diverse needs of children whose parents abuse substances. Curr Drug Abuse Rev 5(2):135-147

24. Burt CH, Simons RL, Gibbons FX (2012) Racial discrimination, ethnic-racial socialization, and crime: a micro-sociological model of risk and resilience. Am Sociol Rev 77(4):648-677. doi:10.1177/ 0003122412448648

25. Gallo LC, Penedo FJ, Espinosa de los Monteros K, Arguelles W (2009) Resiliency in the face of disadvantage: do Hispanic cultural characteristics protect health outcomes? J Pers 77(6):1707-1746. doi:10.1111/j.1467-6494.2009.00598.x

26. Ungar M (2013) Resilience, trauma, context, and culture. Trauma Violence Abuse 14(3):255-266. doi:10.1177/1524838013487805

27. Jablonka E (2012) Epigenetic variations in heredity and evolution. Clin Pharmacol Ther 92(6):683-688. doi:10.1038/clpt.2012.158

28. Inagaki A, Schoenmakers S, Baarends WM (2010) DNA double strand break repair, chromosome synapsis and transcriptional silencing in meiosis. Epigenetics 5(4):255-266

29. Kota SK, Feil R (2010) Epigenetic transitions in germ cell development and meiosis. Dev Cell 19(5):675-686. doi:10.1016/j.devcel.2010.10. 009

30. Marques CJ, Joao Pinho M, Carvalho F, Bieche I, Barros A, Sousa M (2011) DNA methylation imprinting marks and DNA methyltransferase expression in human spermatogenic cell stages. Epigenetics 6(11):1354-1361. doi:10.4161/epi.6.11.17993

31. Gelato KA, Fischle W (2008) Role of histone modifications in defining chromatin structure and function. Biol Chem 389(4):353363. doi:10.1515/BC.2008.048

32. Smith ZD, Meissner A (2013) DNA methylation: roles in mammalian development. Nat Rev Genet 14(3):204-220. doi:10.1038/ $\operatorname{nrg} 3354$

33. Horn PJ, Peterson CL (2002) Molecular biology. Chromatin higher order folding - wrapping up transcription. Sci 297(5588):18241827. doi:10.1126/science. 1074200

34. Yap KL, Zhou MM (2006) Structure and function of protein modules in chromatin biology. Results Probl Cell Differ 41:1-23

35. Rando OJ, Ahmad K (2007) Rules and regulation in the primary structure of chromatin. Curr Opin Cell Biol 19(3):250-256. doi:10. 1016/j.ceb.2007.04.006

36. Mottet D, Castronovo V (2008) Histone deacetylases: target enzymes for cancer therapy. Clin Exp Metastasis 25(2):183-189. doi: 10.1007/s10585-007-9131-5

37. Rossetto D, Avvakumov N, Cote J (2012) Histone phosphorylation: a chromatin modification involved in diverse nuclear events. Epigenetics 7(10):1098-1108. doi:10.4161/epi.21975

38. Shukla A, Chaurasia P, Bhaumik SR (2009) Histone methylation and ubiquitination with their cross-talk and roles in gene expression and stability. Cell Mol Life Sci 66(8):1419-1433. doi:10.1007/ s00018-008-8605-1
39. Kalkhoven E (2004) CBP and p300: HATs for different occasions. Biochem Pharmacol 68(6):1145-1155. doi:10.1016/j. bcp.2004.03.045

40. Sheikh BN (2014) Crafting the brain - role of histone acetyltransferases in neural development and disease. Cell Tissue Res 356(3): 553-573. doi:10.1007/s00441-014-1835-7

41. Parra M, Verdin E (2010) Regulatory signal transduction pathways for class IIa histone deacetylases. Curr Opin Pharmacol 10(4):454 460. doi:10.1016/j.coph.2010.04.004

42. Codd R, Braich N, Liu J, Soe CZ, Pakchung AA (2009) Zn(II)dependent histone deacetylase inhibitors: suberoylanilide hydroxamic acid and trichostatin $\mathrm{A}$. Int $\mathrm{J}$ Biochem Cell Biol 41(4):736-739. doi:10.1016/j.biocel.2008.05.026

43. Neugebauer RC, Sippl W, Jung M (2008) Inhibitors of NAD+ dependent histone deacetylases (sirtuins). Curr Pharm Des 14(6): $562-573$

44. Black JC, Van Rechem C, Whetstine JR (2012) Histone lysine methylation dynamics: establishment, regulation, and biological impact. Mol Cell 48(4):491-507. doi:10.1016/j.molcel.2012.11.006

45. Bernstein BE, Mikkelsen TS, Xie X, Kamal M, Huebert DJ, Cuff J, Fry B, Meissner A, Wernig M, Plath K, Jaenisch R, Wagschal A, Feil R, Schreiber SL, Lander ES (2006) A bivalent chromatin structure marks key developmental genes in embryonic stem cells. Cell 125(2):315-326. doi:10.1016/j.cell.2006.02.041

46. Moss TJ, Wallrath LL (2007) Connections between epigenetic gene silencing and human disease. Mutat Res 618(1-2):163-174. doi:10. 1016/j.mrfmmm.2006.05.038

47. Cloos PA, Christensen J, Agger K, Helin K (2008) Erasing the methyl mark: histone demethylases at the center of cellular differentiation and disease. Genes Dev 22(9):1115-1140. doi:10.1101/ gad.1652908

48. Falkenberg KJ, Johnstone RW (2014) Histone deacetylases and their inhibitors in cancer, neurological diseases and immune disorders. Nat Rev Drug Discov 13(9):673-691. doi: $10.1038 / \operatorname{nrd} 4360$

49. Helin K, Dhanak D (2013) Chromatin proteins and modifications as drug targets. Nat 502(7472):480-488. doi:10.1038/nature12751

50. Branco MR, Ficz G, Reik W (2012) Uncovering the role of 5hydroxymethylcytosine in the epigenome. Nat Rev Genet 13(1): 7-13. doi: $10.1038 / \mathrm{nrg} 3080$

51. Jeltsch A, Jurkowska RZ (2014) New concepts in DNA methylation. Trends Biochem Sci 39(7):310-318. doi:10.1016/j.tibs.2014. 05.002

52. Kinney SR, Pradhan S (2011) Regulation of expression and activity of DNA (cytosine-5) methyltransferases in mammalian cells. Prog Mol Biol Transl Sci 101:311-333. doi:10.1016/B978-0-12-3876850.00009-3

53. Kinney SR, Pradhan S (2013) Ten eleven translocation enzymes and 5-hydroxymethylation in mammalian development and cancer. Adv Exp Med Biol 754:57-79. doi:10.1007/978-1-4419-9967-2_3

54. Dekker AD, De Deyn PP, Rots MG (2014) Epigenetics: the neglected key to minimize learning and memory deficits in Down syndrome. Neurosci Biobehav Rev 45:72-84. doi:10.1016/j. neubiorev.2014.05.004

55. Koch MW, Metz LM, Kovalchuk O (2013) Epigenetic changes in patients with multiple sclerosis. Nat Rev Neurol 9(1):35-43. doi:10. 1038/nrneurol.2012.226

56. Puckett RE, Lubin FD (2011) Epigenetic mechanisms in experience-driven memory formation and behavior. Epigenomics 3(5):649-664. doi:10.2217/epi.11.86

57. Zovkic IB, Guzman-Karlsson MC, Sweatt JD (2013) Epigenetic regulation of memory formation and maintenance. Learn Mem 20(2):61-74. doi:10.1101/lm.026575.112

58. Cadet JL, Brannock C, Jayanthi S, Krasnova IN (2014) Transcriptional and epigenetic substrates of methamphetamine addiction and withdrawal: evidence from a long-access self- 
administration model in the rat. Mol Neurobiol. doi:10.1007/s12035014-8776-8

59. Jayanthi S, McCoy MT, Chen B, Britt JP, Kourrich S, Yau HJ, Ladenheim B, Krasnova IN, Bonci A, Cadet JL (2014) Methamphetamine downregulates striatal glutamate receptors via diverse epigenetic mechanisms. Biol Psychiatr 76(1):47-56. doi:10. 1016/j.biopsych.2013.09.034

60. Krasnova IN, Chiflikyan M, Justinova Z, McCoy MT, Ladenheim B, Jayanthi S, Quintero C, Brannock C, Barnes C, Adair JE, Lehrmann E, Kobeissy FH, Gold MS, Becker KG, Goldberg SR, Cadet JL (2013) CREB phosphorylation regulates striatal transcriptional responses in the self-administration model of methamphetamine addiction in the rat. Neurobiol Dis 58:132-143. doi:10.1016/ j.nbd.2013.05.009

61. McQuown SC, Wood MA (2010) Epigenetic regulation in substance use disorders. Curr Psychiatr Rep 12(2):145-153. doi:10. 1007/s11920-010-0099-5

62. Robison AJ, Nestler EJ (2011) Transcriptional and epigenetic mechanisms of addiction. Nat Rev Neurosci 12(11):623-637. doi:10. 1038/nrn3111

63. Chen J, Evans AN, Liu Y, Honda M, Saavedra JM, Aguilera G (2012) Maternal deprivation in rats is associated with corticotrophin-releasing hormone $(\mathrm{CRH})$ promoter hypomethylation and enhances $\mathrm{CRH}$ transcriptional responses to stress in adulthood. J Neuroendocrinol 24(7):1055-1064. doi:10.1111/j.13652826.2012.02306.x

64. Gray JD, Rubin TG, Hunter RG, McEwen BS (2013) Hippocampal gene expression changes underlying stress sensitization and recovery. Mol Psychiatr. doi:10.1038/mp.2013.175

65. Zannas AS, West AE (2014) Epigenetics and the regulation of stress vulnerability and resilience. Neurosci 264:157-170. doi:10.1016/j. neuroscience.2013.12.003

66. Chen E, Cohen S, Miller GE (2010) How low socioeconomic status affects 2-year hormonal trajectories in children. Psychol Sci 21(1): 31-37. doi:10.1177/0956797609355566

67. Cohen S, Janicki-Deverts D, Miller GE (2007) Psychological stress and disease. Jama 298(14):1685-1687. doi:10.1001/jama.298.14. 1685

68. Austenfeld JL, Stanton AL (2004) Coping through emotional approach: a new look at emotion, coping, and health-related outcomes. J Pers 72(6):1335-1363. doi:10.1111/j.1467-6494.2004.00299.x

69. Harvell CD (1990) The ecology and evolution of inducible defenses. Q Rev Biol 65(3):323-340

70. Lazarus RS (2000) Toward better research on stress and coping. Am Psychol 55(6):665-673

71. McEwen BS (2013) The brain on stress: toward an integrative approach to brain, body and behavior. Perspect Psychol Sci 8(6): 673-675. doi:10.1177/1745691613506907

72. Chakravarty S, Pathak SS, Maitra S, Khandelwal N, Chandra KB, Kumar A (2014) Epigenetic regulatory mechanisms in stressinduced behavior. Int Rev Neurobiol 115:117-154. doi:10.1016/ B978-0-12-801311-3.00004-4

73. Fuchikami M, Morinobu S, Kurata A, Yamamoto S, Yamawaki S (2009) Single immobilization stress differentially alters the expression profile of transcripts of the brain-derived neurotrophic factor (BDNF) gene and histone acetylation at its promoters in the rat hippocampus. Int J Neuropsychopharmacol 12(1):73-82. doi:10. 1017/S1461145708008997

74. Kenworthy CA, Sengupta A, Luz SM, Ver Hoeve ES, Meda K, Bhatnagar S, Abel T (2014) Social defeat induces changes in histone acetylation and expression of histone modifying enzymes in the ventral hippocampus, prefrontal cortex, and dorsal raphe nucleus. Neurosci 264:88-98. doi:10.1016/j. neuroscience.2013.01.024

75. Schouten M, Aschrafi A, Bielefeld P, Doxakis E, Fitzsimons CP (2013) microRNAs and the regulation of neuronal plasticity under stress conditions. Neurosci 241:188-205. doi:10.1016/j. neuroscience.2013.02.065

76. Berton O, McClung CA, Dileone RJ, Krishnan V, Renthal W, Russo SJ, Graham D, Tsankova NM, Bolanos CA, Rios M, Monteggia LM, Self DW, Nestler EJ (2006) Essential role of BDNF in the mesolimbic dopamine pathway in social defeat stress. Sci 311(5762):864-868. doi:10.1126/science.1120972

77. Krishnan V, Han MH, Graham DL, Berton O, Renthal W, Russo SJ, Laplant Q, Graham A, Lutter M, Lagace DC, Ghose S, Reister R, Tannous P, Green TA, Neve RL, Chakravarty S, Kumar A, Eisch AJ, Self DW, Lee FS, Tamminga CA, Cooper DC, Gershenfeld HK, Nestler EJ (2007) Molecular adaptations underlying susceptibility and resistance to social defeat in brain reward regions. Cell 131(2): 391-404. doi:10.1016/j.cell.2007.09.018

78. Roth TL, Zoladz PR, Sweatt JD, Diamond DM (2011) Epigenetic modification of hippocampal Bdnf DNA in adult rats in an animal model of post-traumatic stress disorder. J Psychiatr Res 45(7):919926. doi:10.1016/j.jpsychires.2011.01.013

79. Renthal W, Maze I, Krishnan V, Covington HE 3rd, Xiao G, Kumar A, Russo SJ, Graham A, Tsankova N, Kippin TE, Kerstetter KA, Neve RL, Haggarty SJ, McKinsey TA, Bassel-Duby R, Olson EN, Nestler EJ (2007) Histone deacetylase 5 epigenetically controls behavioral adaptations to chronic emotional stimuli. Neuron 56(3): 517-529. doi:10.1016/j.neuron.2007.09.032

80. Covington HE 3rd, Maze I, LaPlant QC, Vialou VF, Ohnishi YN, Berton O, Fass DM, Renthal W, Rush AJ 3rd, Wu EY, Ghose S, Krishnan V, Russo SJ, Tamminga C, Haggarty SJ, Nestler EJ (2009) Antidepressant actions of histone deacetylase inhibitors. J Neurosci 29(37):11451-11460. doi:10.1523/ JNEUROSCI. 1758-09.2009

81. Covington HE 3rd, Maze I, Sun H, Bomze HM, DeMaio KD, Wu EY, Dietz DM, Lobo MK, Ghose S, Mouzon E, Neve RL, Tamminga CA, Nestler EJ (2011) A role for repressive histone methylation in cocaine-induced vulnerability to stress. Neuron 71(4):656-670. doi:10.1016/j.neuron.2011.06.007

82. Shankar SR, Bahirvani AG, Rao VK, Bharathy N, Ow JR, Taneja R (2013) G9a, a multipotent regulator of gene expression. Epigenetics 8(1):16-22. doi:10.4161/epi.23331

83. Hollis F, Duclot F, Gunjan A, Kabbaj M (2011) Individual differences in the effect of social defeat on anhedonia and histone acetylation in the rat hippocampus. Horm Behav 59(3):331-337. doi:10. 1016/j.yhbeh.2010.09.005

84. Hooks MS, Jones GH, Smith AD, Neill DB, Justice JB Jr (1991) Response to novelty predicts the locomotor and nucleus accumbens dopamine response to cocaine. Synapse 9(2):121-128. doi:10.1002/ syn.890090206

85. Kabbaj M, Devine DP, Savage VR, Akil H (2000) Neurobiological correlates of individual differences in novelty-seeking behavior in the rat: differential expression of stress-related molecules. J Neurosci 20(18):6983-6988

86. Hooks MS, Colvin AC, Juncos JL, Justice JB Jr (1992) Individual differences in basal and cocaine-stimulated extracellular dopamine in the nucleus accumbens using quantitative microdialysis. Brain Res 587(2):306-312

87. Kabbaj M, Akil H (2001) Individual differences in novelty-seeking behavior in rats: a c-fos study. Neurosci 106(3):535-545

88. Fukuda H, Sano N, Muto S, Horikoshi M (2006) Simple histone acetylation plays a complex role in the regulation of gene expression. Brief Funct Genomic Proteomic 5(3):190-208. doi:10.1093/ bfgp/ello32

89. Janknecht R (2002) The versatile functions of the transcriptional coactivators p300 and CBP and their roles in disease. Histol Histopathol 17(2):657-668

90. Levine AA, Guan Z, Barco A, Xu S, Kandel ER, Schwartz JH (2005) CREB-binding protein controls response to cocaine by acetylating histones at the fosB promoter in the mouse 
striatum. Proc Natl Acad Sci U S A 102(52):19186-19191. doi:10.1073/pnas.0509735102

91. Malvaez M, Mhillaj E, Matheos DP, Palmery M, Wood MA (2011) CBP in the nucleus accumbens regulates cocaineinduced histone acetylation and is critical for cocaineassociated behaviors. J Neurosci 31(47):16941-16948. doi:10. 1523/JNEUROSCI. 2747-11.2011

92. Roth TL, Lubin FD, Funk AJ, Sweatt JD (2009) Lasting epigenetic influence of early-life adversity on the BDNF gene. Biol Psychiatr 65(9):760-769. doi:10.1016/j.biopsych.2008.11.028

93. Jia R, Tai F, An S, Zhang X, Broders H (2009) Effects of neonatal paternal deprivation or early deprivation on anxiety and social behaviors of the adults in mandarin voles. Behav Process 82(3): 271-278. doi:10.1016/j.beproc.2009.07.006

94. Moffett MC, Harley J, Francis D, Sanghani SP, Davis WI, Kuhar MJ (2006) Maternal separation and handling affects cocaine selfadministration in both the treated pups as adults and the dams. J Pharmacol Exp Ther 317(3):1210-1218. doi:10.1124/jpet.106. 101139

95. McGowan PO, Suderman M, Sasaki A, Huang TC, Hallett M, Meaney MJ, Szyf M (2011) Broad epigenetic signature of maternal care in the brain of adult rats. PLoS One 6(2):e14739. doi:10.1371/ journal.pone.0014739

96. McGowan PO, Szyf M (2010) Environmental epigenomics: understanding the effects of parental care on the epigenome. Essays Biochem 48(1):275-287. doi:10.1042/bse0480275

97. Oberlander TF, Weinberg J, Papsdorf M, Grunau R, Misri S, Devlin AM (2008) Prenatal exposure to maternal depression, neonatal methylation of human glucocorticoid receptor gene (NR3C1) and infant cortisol stress responses. Epigenetics 3(2):97-106

98. McGowan PO, Sasaki A, D'Alessio AC, Dymov S, Labonte B, Szyf M, Turecki G, Meaney MJ (2009) Epigenetic regulation of the glucocorticoid receptor in human brain associates with childhood abuse. Nat Neurosci 12(3):342-348. doi:10.1038/nn.2270

99. Perroud N, Paoloni-Giacobino A, Prada P, Olie E, Salzmann A, Nicastro R, Guillaume S, Mouthon D, Stouder C, Dieben K, Huguelet P, Courtet P, Malafosse A (2011) Increased methylation of glucocorticoid receptor gene (NR3C1) in adults with a history of childhood maltreatment: a link with the severity and type of trauma. Transl Psychiatr 1:e59. doi:10.1038/tp.2011.60

100. Tyrka AR, Price LH, Marsit C, Walters OC, Carpenter LL (2012) Childhood adversity and epigenetic modulation of the leukocyte glucocorticoid receptor: preliminary findings in healthy adults. PLoS One 7(1):e30148. doi:10.1371/journal.pone.0030148

101. Bohacek J, Farinelli M, Mirante O, Steiner G, Gapp K, Coiret G, Ebeling M, Duran-Pacheco G, Iniguez AL, Manuella F, Moreau JL, Mansuy IM (2014) Pathological brain plasticity and cognition in the offspring of males subjected to postnatal traumatic stress. Mol Psychiatr. doi:10.1038/mp.2014.80

102. Hunter RG, McEwen BS (2013) Stress and anxiety across the lifespan: structural plasticity and epigenetic regulation. Epigenomics 5(2):177-194. doi:10.2217/epi.13.8

103. Ruglass LM, Lopez-Castro T, Cheref S, Papini S, Hien DA (2014) At the crossroads: the intersection of substance use disorders, anxiety disorders, and posttraumatic stress disorder. Curr Psychiatr Rep 16(11):505. doi:10.1007/s11920-014-0505-5

104. Sunderland M, Slade T, Krueger RF (2014) Examining the shared and unique relationships among substance use and mental disorders. Psychol Med 17:1-11. doi:10.1017/S0033291714002219

105. Szapocznik J, Prado G, Burlew AK, Williams RA, Santisteban DA (2007) Drug abuse in African American and Hispanic adolescents: culture, development, and behavior. Annu Rev Clin Psychol 3:77105. doi:10.1146/annurev.clinpsy.3.022806.091408

106. Kerns RT, Ravindranathan A, Hassan S, Cage MP, York T, Sikela JM, Williams RW, Miles MF (2005) Ethanol-responsive brain region expression networks: implications for behavioral responses to acute ethanol in DBA/2J versus C57BL/6J mice. J Neurosci 25(9): 2255-2266. doi:10.1523/JNEUROSCI. 4372-04.2005

107. Rodd ZA, Kimpel MW, Edenberg HJ, Bell RL, Strother WN, McClintick JN, Carr LG, Liang T, McBride WJ (2008) Differential gene expression in the nucleus accumbens with ethanol self-administration in inbred alcohol-preferring rats. Pharmacol Biochem Behav 89(4):481-498. doi:10.1016/j.pbb.2008.01.023

108. Finegersh A, Homanics GE (2014) Acute ethanol alters multiple histone modifications at model gene promoters in the cerebral cortex. Alcohol Clin Exp Res 38(7):1865-1873. doi:10.1111/acer. 12465

109. Ponomarev I (2013) Epigenetic control of gene expression in the alcoholic brain. Alcohol Res 35(1):69-76

110. Pandey SC, Ugale R, Zhang H, Tang L, Prakash A (2008) Brain chromatin remodeling: a novel mechanism of alcoholism. J Neurosci 28(14):3729-3737. doi:10.1523/JNEUROSCI. 5731-07. 2008

111. D'Addario C, Caputi FF, Ekstrom TJ, Di Benedetto M, Maccarrone M, Romualdi P, Candeletti S (2013) Ethanol induces epigenetic modulation of prodynorphin and pronociceptin gene expression in the rat amygdala complex. J Mol Neurosci 49(2):312-319. doi:10. 1007/s12031-012-9829-y

112. Qiang M, Denny A, Lieu M, Carreon S, Li J (2011) Histone H3K9 modifications are a local chromatin event involved in ethanolinduced neuroadaptation of the NR2B gene. Epigenetics 6(9): 1095-1104. doi:10.4161/epi.6.9.16924

113. Zhou Z, Yuan Q, Mash DC, Goldman D (2011) Substance-specific and shared transcription and epigenetic changes in the human hippocampus chronically exposed to cocaine and alcohol. Proc Natl Acad Sci U S A 108(16):6626-6631. doi:10.1073/pnas. 1018514108

114. Ponomarev I, Wang S, Zhang L, Harris RA, Mayfield RD (2012) Gene coexpression networks in human brain identify epigenetic modifications in alcohol dependence. J Neurosci 32(5):18841897. doi:10.1523/JNEUROSCI. 3136-11.2012

115. Manzardo AM, Henkhaus RS, Butler MG (2012) Global DNA promoter methylation in frontal cortex of alcoholics and controls. Gene 498(1):5-12. doi:10.1016/j.gene.2012.01.096

116. Albertson DN, Schmidt CJ, Kapatos G, Bannon MJ (2006) Distinctive profiles of gene expression in the human nucleus accumbens associated with cocaine and heroin abuse. Neuropsychopharmacol 31(10):2304-2312. doi:10.1038/sj.npp. 1301089

117. Freeman WM, Nader MA, Nader SH, Robertson DJ, Gioia L, Mitchell SM, Daunais JB, Porrino LJ, Friedman DP, Vrana KE (2001) Chronic cocaine-mediated changes in non-human primate nucleus accumbens gene expression. J Neurochem 77(2):542-549

118. Freeman WM, Patel KM, Brucklacher RM, Lull ME, Erwin M, Morgan D, Roberts DC, Vrana KE (2008) Persistent alterations in mesolimbic gene expression with abstinence from cocaine selfadministration. Neuropsychopharmacol 33(8):1807-1817. doi:10. 1038/sj.npp.1301577

119. Rogge GA, Wood MA (2013) The role of histone acetylation in cocaine-induced neural plasticity and behavior. Neuropsychopharmacol 38(1):94-110. doi:10.1038/npp.2012.154

120. Kumar A, Choi KH, Renthal W, Tsankova NM, Theobald DE, Truong HT, Russo SJ, Laplant Q, Sasaki TS, Whistler KN, Neve RL, Self DW, Nestler EJ (2005) Chromatin remodeling is a key mechanism underlying cocaine-induced plasticity in striatum. Neuron 48(2):303-314. doi:10.1016/j.neuron.2005.09.023

121. Romieu P, Host L, Gobaille S, Sandner G, Aunis D, Zwiller J (2008) Histone deacetylase inhibitors decrease cocaine but not sucrose selfadministration in rats. J Neurosci 28(38):9342-9348. doi:10.1523/ JNEUROSCI. 0379-08.2008

122. Host L, Dietrich JB, Carouge D, Aunis D, Zwiller J (2011) Cocaine self-administration alters the expression of chromatin-remodelling 
proteins; modulation by histone deacetylase inhibition. J Psychopharmacol 25(2):222-229. doi:10.1177/0269881109348173

123. Taniguchi M, Carreira MB, Smith LN, Zirlin BC, Neve RL, Cowan CW (2012) Histone deacetylase 5 limits cocaine reward through cAMP-induced nuclear import. Neuron 73(1):108-120. doi:10. 1016/j.neuron.2011.10.032

124. Kennedy PJ, Feng J, Robison AJ, Maze I, Badimon A, Mouzon E, Chaudhury D, Damez-Werno DM, Haggarty SJ, Han MH, BasselDuby R, Olson EN, Nestler EJ (2013) Class I HDAC inhibition blocks cocaine-induced plasticity by targeted changes in histone methylation. Nat Neurosci 16(4):434-440. doi:10.1038/nn.3354

125. Rogge GA, Singh H, Dang R, Wood MA (2013) HDAC3 is a negative regulator of cocaine-context-associated memory formation. J Neurosci 33(15):6623-6632. doi:10.1523/JNEUROSCI. 4472-12.2013

126. Wang L, Lv Z, Hu Z, Sheng J, Hui B, Sun J, Ma L (2010) Chronic cocaine-induced $\mathrm{H} 3$ acetylation and transcriptional activation of CaMKIIalpha in the nucleus accumbens is critical for motivation for drug reinforcement. Neuropsychopharmacol 35(4):913-928. doi:10.1038/npp.2009.193

127. Ferguson D, Koo JW, Feng J, Heller E, Rabkin J, Heshmati M, Renthal W, Neve R, Liu X, Shao N, Sartorelli V, Shen L, Nestler EJ (2013) Essential role of SIRT1 signaling in the nucleus accumbens in cocaine and morphine action. J Neurosci 33(41):16088-16098. doi:10.1523/JNEUROSCI. 1284-13.2013

128. Renthal W, Kumar A, Xiao G, Wilkinson M, Covington HE 3rd, Maze I, Sikder D, Robison AJ, LaPlant Q, Dietz DM, Russo SJ, Vialou V, Chakravarty S, Kodadek TJ, Stack A, Kabbaj M, Nestler EJ (2009) Genome-wide analysis of chromatin regulation by cocaine reveals a role for sirtuins. Neuron 62(3):335-348. doi:10. 1016/j.neuron.2009.03.026

129. Hell JW (2014) CaMKII: claiming center stage in postsynaptic function and organization. Neuron 81(2):249-265. doi:10.1016/j. neuron.2013.12.024

130. Grimm JW, Lu L, Hayashi T, Hope BT, Su TP, Shaham Y (2003) Time-dependent increases in brain-derived neurotrophic factor protein levels within the mesolimbic dopamine system after withdrawal from cocaine: implications for incubation of cocaine craving. J Neurosci 23(3):742-747

131. Schmidt HD, Sangrey GR, Darnell SB, Schassburger RL, Cha JH, Pierce RC, Sadri-Vakili G (2012) Increased brainderived neurotrophic factor (BDNF) expression in the ventral tegmental area during cocaine abstinence is associated with increased histone acetylation at BDNF exon I-containing promoters. J Neurochem 120(2):202-209. doi:10.1111/j. 1471-4159.2011.07571.x

132. Schroeder FA, Penta KL, Matevossian A, Jones SR, Konradi C, Tapper AR, Akbarian S (2008) Drug-induced activation of dopamine $\mathrm{D}(1)$ receptor signaling and inhibition of class $\mathrm{I} / \mathrm{II}$ histone deacetylase induce chromatin remodeling in reward circuitry and modulate cocaine-related behaviors. Neuropsychopharmacol 33(12):2981-2992. doi:10.1038/npp.2008.15

133. Maze I, Covington HE 3rd, Dietz DM, LaPlant Q, Renthal W, Russo SJ, Mechanic M, Mouzon E, Neve RL, Haggarty SJ, Ren Y, Sampath SC, Hurd YL, Greengard P, Tarakhovsky A, Schaefer A, Nestler EJ (2010) Essential role of the histone methyltransferase G9a in cocaine-induced plasticity. Sci 327(5962):213-216. doi:10. 1126/science. 1179438

134. Tomasiewicz HC, Jacobs MM, Wilkinson MB, Wilson SP, Nestler EJ, Hurd YL (2012) Proenkephalin mediates the enduring effects of adolescent cannabis exposure associated with adult opiate vulnerability. Biol Psychiatr 72(10):803-810. doi:10.1016/j.biopsych. 2012.04.026

135. Pol Bodetto S, Carouge D, Fonteneau M, Dietrich JB, Zwiller J, Anglard P (2013) Cocaine represses protein phosphatase-1Cbeta through DNA methylation and Methyl-CpG Binding Protein-2 recruitment in adult rat brain. Neuropharmacol 73:31-40. doi:10. 1016/j.neuropharm.2013.05.005

136. Deng JV, Wan Y, Wang X, Cohen S, Wetsel WC, Greenberg ME, Kenny PJ, Calakos N, West AE (2014) MeCP2 phosphorylation limits psychostimulant-induced behavioral and neuronal plasticity. J Neurosci 34(13):4519-4527. doi:10.1523/ JNEUROSCI. 2821-13.2014

137. Mao LM, Horton E, Guo ML, Xue B, Jin DZ, Fibuch EE, Wang JQ (2011) Cocaine increases phosphorylation of MeCP2 in the rat striatum in vivo: a differential role of NMDA receptors. Neurochem Int 59(5):610-617. doi:10.1016/j.neuint.2011.04.013

138. Im HI, Hollander JA, Bali P, Kenny PJ (2010) MeCP2 controls BDNF expression and cocaine intake through homeostatic interactions with microRNA-212. Nat Neurosci 13(9):1120-1127. doi:10. 1038/nn.2615

139. Anier K, Malinovskaja K, Aonurm-Helm A, Zharkovsky A, Kalda A (2010) DNA methylation regulates cocaine-induced behavioral sensitization in mice. Neuropsychopharmacol 35(12):2450-2461. doi:10.1038/npp.2010.128

140. Cadet JL, Krasnova IN (2009) Molecular bases of methamphetamine-induced neurodegeneration. Int Rev Neurobiol 88:101-119. doi:10.1016/S0074-7742(09)88005-7

141. Krasnova IN, Marchant NJ, Ladenheim B, McCoy MT, Panlilio LV, Bossert JM, Shaham Y, Cadet JL (2014) Incubation of methamphetamine and palatable food craving after punishment-induced abstinence. Neuropsychopharmacol 39(8):2008-2016. doi:10.1038/npp. 2014.50

142. Cadet JL, Brannock C, Ladenheim B, McCoy MT, Krasnova IN, Lehrmann E, Becker KG, Jayanthi S (2014) Enhanced upregulation of CRH mRNA expression in the nucleus accumbens of male rats after a second injection of methamphetamine given thirty days later. PLoS One 9(1):e84665. doi:10.1371/journal.pone.0084665

143. Wang J, Yuan W, Li MD (2011) Genes and pathways co-associated with the exposure to multiple drugs of abuse, including alcohol, amphetamine/methamphetamine, cocaine, marijuana, morphine, and/or nicotine: a review of proteomics analyses. Mol Neurobiol 44(3):269-286. doi:10.1007/s12035-011-8202-4

144. Martin TA, Jayanthi S, McCoy MT, Brannock C, Ladenheim B, Garrett T, Lehrmann E, Becker KG, Cadet JL (2012) Methamphetamine causes differential alterations in gene expression and patterns of histone acetylation/hypoacetylation in the rat nucleus accumbens. PLoS One 7(3):e34236. doi:10.1371/journal.pone.0034236

145. Harkness JH, Hitzemann RJ, Edmunds S, Phillips TJ (2013) Effects of sodium butyrate on methamphetamine-sensitized locomotor activity. Behav Brain Res 239:139-147. doi:10.1016/j.bbr.2012.10.046

146. Cadet JL, Jayanthi S, McCoy MT, Ladenheim B, Saint-Preux F, Lehrmann E, De S, Becker KG, Brannock C (2013) Genome-wide profiling identifies a subset of methamphetamine (METH)-induced genes associated with METH-induced increased H4K5Ac binding in the rat striatum. BMC Genomics 14:545. doi:10.1186/14712164-14-545

147. Henry RA, Kuo YM, Andrews AJ (2013) Differences in specificity and selectivity between CBP and p300 acetylation of histone $\mathrm{H} 3$ and H3/H4. Biochem 52(34):5746-5759. doi:10.1021/bi400684q

148. Nogueiras R, Habegger KM, Chaudhary N, Finan B, Banks AS, Dietrich MO, Horvath TL, Sinclair DA, Pfluger PT, Tschop MH (2012) Sirtuin 1 and sirtuin 3: physiological modulators of metabolism. Physiol Rev 92(3):1479-1514. doi:10.1152/physrev.00022.2011

149. Park J, Chen Y, Tishkoff DX, Peng C, Tan M, Dai L, Xie Z, Zhang Y, Zwaans BM, Skinner ME, Lombard DB, Zhao Y (2013) SIRT5-mediated lysine desuccinylation impacts diverse metabolic pathways. Mol Cell 50(6):919-930. doi:10.1016/j. molcel.2013.06.001

150. Ballas N, Mandel G (2005) The many faces of REST oversee epigenetic programming of neuronal genes. Curr Opin Neurobiol 15(5):500-506. doi:10.1016/j.conb.2005.08.015 
151. Kelly RD, Cowley SM (2013) The physiological roles of histone deacetylase (HDAC) 1 and 2: complex co-stars with multiple leading parts. Biochem Soc Trans 41(3):741-749. doi:10.1042/ BST20130010

152. Qureshi IA, Gokhan S, Mehler MF (2010) REST and CoREST are transcriptional and epigenetic regulators of seminal neural fate decisions. Cell Cycle 9(22):4477-4486

153. Aguilar-Valles A, Vaissiere T, Griggs EM, Mikaelsson MA, Takacs IF, Young EJ, Rumbaugh G, Miller CA (2014) Methamphetamineassociated memory is regulated by a writer and an eraser of permissive histone methylation. Biol Psychiatr 76(1):57-65. doi:10.1016/j. biopsych.2013.09.014

154. Lewis CR, Staudinger K, Scheck L, Olive MF (2013) The effects of maternal separation on adult methamphetamine self-administration, extinction, reinstatement, and $\mathrm{MeCP} 2$ immunoreactivity in the nucleus accumbens. Front Psychiatr 4:55. doi:10.3389/fpsyt.2013.00055

155. Numachi Y, Shen H, Yoshida S, Fujiyama K, Toda S, Matsuoka H, Sora I, Sato M (2007) Methamphetamine alters expression of DNA methyltransferase 1 mRNA in rat brain. Neurosci Lett 414(3):213217. doi:10.1016/j.neulet.2006.12.052

156. Itzhak Y, Ergui I, Young JI (2014) Long-term parental methamphetamine exposure of mice influences behavior and hippocampal DNA methylation of the offspring. Mol Psychiatr. doi:10.1038/mp.2014.7

157. Doura MB, Luu TV, Lee NH, Perry DC (2010) Persistent gene expression changes in ventral tegmental area of adolescent but not adult rats in response to chronic nicotine. Neurosci 170(2):503-513. doi:10.1016/j.neuroscience.2010.06.071

158. Li MD, Kane JK, Wang J, Ma JZ (2004) Time-dependent changes in transcriptional profiles within five rat brain regions in response to nicotine treatment. Brain Res Mol Brain Res 132(2):168-180. doi: 10.1016/j.molbrainres.2004.09.009

159. Kandel ER, Kandel DB (2014) Shattuck Lecture. A molecular basis for nicotine as a gateway drug. N Engl J Med 371(10):932-943. doi: 10.1056/NEJMsa1405092

160. Levine A, Huang Y, Drisaldi B, Griffin EA Jr, Pollak DD, Xu S, Yin D, Schaffran C, Kandel DB, Kandel ER (2011) Molecular mechanism for a gateway drug: epigenetic changes initiated by nicotine prime gene expression by cocaine. Sci Transl Med 3(107): 107ra109. doi:10.1126/scitranslmed.3003062

161. Huang YY, Kandel DB, Kandel ER, Levine A (2013) Nicotine primes the effect of cocaine on the induction of LTP in the amygdala. Neuropharmacol 74:126-134. doi:10.1016/j.neuropharm. 2013.03.031

162. Gozen O, Balkan B, Yildirim E, Koylu EO, Pogun S (2013) The epigenetic effect of nicotine on dopamine $\mathrm{D} 1$ receptor expression in rat prefrontal cortex. Synapse 67(9):545-552. doi:10.1002/syn. 21659

163. Chase KA, Sharma RP (2013) Nicotine induces chromatin remodelling through decreases in the methyltransferases GLP, G9a, Setdb1 and levels of H3K9me2. Int J Neuropsychopharmacol 16(5):1129-1138. doi:10.1017/S1461145712001101

164. Satta R, Maloku E, Zhubi A, Pibiri F, Hajos M, Costa E, Guidotti A (2008) Nicotine decreases DNA methyltransferase 1 expression and glutamic acid decarboxylase 67 promoter methylation in GABAergic interneurons. Proc Natl Acad Sci U S A 105(42): 16356-16361. doi:10.1073/pnas.0808699105

165. Fanous S, Guez-Barber DH, Goldart EM, Schrama R, Theberge FR, Shaham Y, Hope BT (2013) Unique gene alterations are induced in FACS-purified Fos-positive neurons activated during cue-induced relapse to heroin seeking. J Neurochem 124(1):100-108. doi:10. 1111/jnc. 12074

166. Piechota M, Korostynski M, Sikora M, Golda S, Dzbek J, Przewlocki R (2012) Common transcriptional effects in the mouse striatum following chronic treatment with heroin and methamphetamine. Genes Brain Behav 11(4):404-414. doi:10.1111/j.1601183X.2012.00777.x
167. Sheng J, Lv Z, Wang L, Zhou Y, Hui B (2011) Histone H3 phosphoacetylation is critical for heroin-induced place preference. Neuroreport 22(12):575-580. doi:10.1097/WNR. 0b013e328348e6aa

168. Wang Y, Lai J, Cui H, Zhu Y, Zhao B, Wang W, Wei S (2014) Inhibition of histone deacetylase in the basolateral amygdala facilitates morphine context-associated memory formation in rats. J Mol Neurosci. doi:10.1007/s12031-014-0317-4

169. Mashayekhi FJ, Rasti M, Rahvar M, Mokarram P, Namavar MR, Owji AA (2012) Expression levels of the BDNF gene and histone modifications around its promoters in the ventral tegmental area and locus ceruleus of rats during forced abstinence from morphine. Neurochem Res 37(7):1517-1523. doi:10.1007/s11064-012-07469

170. Ciccarelli A, Calza A, Santoru F, Grasso F, Concas A, SassoePognetto M, Giustetto M (2013) Morphine withdrawal produces ERK-dependent and ERK-independent epigenetic marks in neurons of the nucleus accumbens and lateral septum. Neuropharmacol 70: 168-179. doi:10.1016/j.neuropharm.2012.12.010

171. Sun H, Maze I, Dietz DM, Scobie KN, Kennedy PJ, Damez-Werno D, Neve RL, Zachariou V, Shen L, Nestler EJ (2012) Morphine epigenomically regulates behavior through alterations in histone $\mathrm{H} 3$ lysine 9 dimethylation in the nucleus accumbens. J Neurosci 32(48): 17454-17464. doi:10.1523/JNEUROSCI. 1357-12.2012

172. Fragou D, Zanos P, Kouidou S, Njau S, Kitchen I, Bailey A, Kovatsi L (2013) Effect of chronic heroin and cocaine administration on global DNA methylation in brain and liver. Toxicol Lett 218(3): 260-265. doi:10.1016/j.toxlet.2013.01.022

173. Campbell-Sills L, Cohan SL, Stein MB (2006) Relationship of resilience to personality, coping, and psychiatric symptoms in young adults. Behav Res Ther 44(4):585-599. doi:10.1016/j.brat. 2005.05.001

174. Hawley DR, DeHaan L (1996) Toward a definition of family resilience: integrating life-span and family perspectives. Fam Process 35(3):283-298

175. Rutter M (1985) Resilience in the face of adversity. Protective factors and resistance to psychiatric disorder. Br J Psychiatr 147: 598-611

176. Rutter M (2012) Resilience as a dynamic concept. Dev Psychopathol 24(2):335-344. doi:10.1017/S0954579412000028

177. Hjemdal O, Aune T, Reinfjell T, Stiles TC, Friborg O (2007) Resilience as a predictor of depressive symptoms: a correlational study with young adolescents. Clin Child Psychol Psychiatr 12(1): 91-104

178. Hjemdal O, Friborg O, Stiles TC (2012) Resilience is a good predictor of hopelessness even after accounting for stressful life events, mood and personality (NEO-PI-R). Scand J Psychol 53(2): 174-180. doi:10.1111/j.1467-9450.2011.00928.x

179. Brody GH, Chen YF, Yu T, Beach SR, Kogan SM, Simons RL, Windle M, Philibert RA (2012) Life stress, the dopamine receptor gene, and emerging adult drug use trajectories: a longitudinal, multilevel, mediated moderation analysis. Dev Psychopathol 24(3):941-951. doi:10.1017/S0954579412000466

180. Brody GH, Yu T, Chen YF, Kogan SM, Evans GW, Beach SR, Windle M, Simons RL, Gerrard M, Gibbons FX, Philibert RA (2013) Cumulative socioeconomic status risk, allostatic load, and adjustment: a prospective latent profile analysis with contextual and genetic protective factors. Dev Psychol 49(5):913-927. doi:10.1037/a0028847

181. Brody GH, Yu T, Chen YF, Kogan SM, Evans GW, Windle M, Gerrard M, Gibbons FX, Simons RL, Philibert RA (2013) Supportive family environments, genes that confer sensitivity, and allostatic load among rural African American emerging adults: a prospective analysis. J Fam Psychol 27(1):22-29. doi:10.1037/a0027829

182. Buka SL (2002) Disparities in health status and substance use: ethnicity and socioeconomic factors. Public Health Rep 117(Suppl 1):S118-S125 
183. Kadushin C, Reber E, Saxe L, Livert D (1998) The substance use system: social and neighborhood environments associated with substance use and misuse. Subst Use Misuse 33(8):16811710

184. McGloin JM, Widom CS (2001) Resilience among abused and neglected children grown up. Dev Psychopathol 13(4):10211038

185. Gibbons FX, Roberts ME, Gerrard M, Li Z, Beach SR, Simons RL, Weng CY, Philibert RA (2012) The impact of stress on the life history strategies of African American adolescents: cognitions, genetic moderation, and the role of discrimination. Dev Psychol 48(3): 722-739. doi:10.1037/a0026599

186. Nobile M, Giorda R, Marino C, Carlet O, Pastore V, Vanzin L, Bellina M, Molteni M, Battaglia M (2007) Socioeconomic status mediates the genetic contribution of the dopamine receptor D4 and serotonin transporter linked promoter region repeat polymorphisms to externalization in preadolescence. Dev Psychopathol 19(4): 1147-1160. doi:10.1017/S0954579407000594

187. Bowes L, Jaffee SR (2013) Biology, genes, and resilience: toward a multidisciplinary approach. Trauma Violence Abuse 14(3):195208. doi:10.1177/1524838013487807

188. Dudley KJ, Li X, Kobor MS, Kippin TE, Bredy TW (2011) Epigenetic mechanisms mediating vulnerability and resilience to psychiatric disorders. Neurosci Biobehav Rev 35(7):1544-1551. doi:10.1016/j.neubiorev.2010.12.016

189. Wilkinson MB, Xiao G, Kumar A, LaPlant Q, Renthal W, Sikder D, Kodadek TJ, Nestler EJ (2009) Imipramine treatment and resiliency exhibit similar chromatin regulation in the mouse nucleus accumbens in depression models. J Neurosci 29(24):7820-7832. doi:10. 1523/JNEUROSCI. 0932-09.2009

190. Uchida S, Hara K, Kobayashi A, Otsuki K, Yamagata H, Hobara T, Suzuki T, Miyata N, Watanabe Y (2011) Epigenetic status of Gdnf in the ventral striatum determines susceptibility and adaptation to daily stressful events. Neuron 69(2):359-372. doi:10.1016/j.neuron. 2010.12.023

191. Agrawal AA (2001) Phenotypic plasticity in the interactions and evolution of species. Sci 294(5541):321-326. doi:10.1126/science. 1060701

192. Walker CD (2010) Maternal touch and feed as critical regulators of behavioral and stress responses in the offspring. Dev Psychobiol 52(7):638-650. doi:10.1002/dev.20492

193. Liu D, Diorio J, Tannenbaum B, Caldji C, Francis D, Freedman A, Sharma S, Pearson D, Plotsky PM, Meaney MJ (1997) Maternal care, hippocampal glucocorticoid receptors, and hypothalamic-pituitary-adrenal responses to stress. Sci 277(5332):1659-1662

194. Weaver IC, Cervoni N, Champagne FA, D'Alessio AC, Sharma S, Seckl JR, Dymov S, Szyf M, Meaney MJ (2004) Epigenetic programming by maternal behavior. Nat Neurosci 7(8):847-854. doi: $10.1038 / \mathrm{nn} 1276$

195. Zhang TY, Labonte B, Wen XL, Turecki G, Meaney MJ (2013) Epigenetic mechanisms for the early environmental regulation of hippocampal glucocorticoid receptor gene expression in rodents and humans. Neuropsychopharmacol 38(1):111-123. doi:10.1038/npp. 2012.149

196. Weaver IC, Champagne FA, Brown SE, Dymov S, Sharma S, Meaney MJ, Szyf M (2005) Reversal of maternal programming of stress responses in adult offspring through methyl supplementation: altering epigenetic marking later in life. J Neurosci 25(47):1104511054. doi:10.1523/JNEUROSCI. 3652-05.2005

197. Champagne F, Meaney MJ (2001) Like mother, like daughter: evidence for non-genomic transmission of parental behavior and stress responsivity. Prog Brain Res 133:287-302

198. Champagne FA, Meaney MJ (2007) Transgenerational effects of social environment on variations in maternal care and behavioral response to novelty. Behav Neurosci 121(6):1353-1363. doi:10. 1037/0735-7044.121.6.1353
199. Gonzalez A, Lovic V, Ward GR, Wainwright PE, Fleming AS (2001) Intergenerational effects of complete maternal deprivation and replacement stimulation on maternal behavior and emotionality in female rats. Dev Psychobiol 38(1):11-32

200. Palombo DJ, Nowoslawski M, Fleming AS (2010) Motherless rats show deficits in maternal behavior towards fostered pups. Dev Psychobiol 52(2):142-148. doi:10.1002/dev.20422

201. Shoji H, Kato K (2009) Maternal care affects the development of maternal behavior in inbred mice. Dev Psychobiol 51(4):345-357. doi:10.1002/dev.20375

202. Mychasiuk R, Harker A, Ilnytskyy S, Gibb R (2013) Paternal stress prior to conception alters DNA methylation and behaviour of developing rat offspring. Neurosci 241:100-105. doi:10.1016/j. neuroscience.2013.03.025

203. Mychasiuk R, Zahir S, Schmold N, Ilnytskyy S, Kovalchuk O, Gibb R (2012) Parental enrichment and offspring development: modifications to brain, behavior and the epigenome. Behav Brain Res 228(2):294-298. doi:10.1016/j.bbr.2011.11.036

204. Mashoodh R, Franks B, Curley JP, Champagne FA (2012) Paternal social enrichment effects on maternal behavior and offspring growth. Proc Natl Acad Sci U S A 109(Suppl 2):17232-17238. doi:10.1073/pnas.1121083109

205. Leshner AI (1997) Addiction is a brain disease, and it matters. Sci 278(5335):45-47

206. Phillips KL, Copeland LA, Zeber JE, Stock EM, Tsan JY, MacCarthy AA (2014) Racial/ethnic disparities in monitoring metabolic parameters for patients with schizophrenia receiving antipsychotic medications. Am J Geriatr Psychiatr. doi:10.1016/j.jagp. 2014.07.007

207. Schoenfeld AJ, Tipirneni R, Nelson JH, Carpenter JE, Iwashyna TJ (2014) The influence of race and ethnicity on complications and mortality after orthopedic surgery: a systematic review of the literature. Med Care 52(9):842-851. doi:10.1097/MLR. 0000000000000177

208. Werner RM, Asch DA, Polsky D (2005) Racial profiling: the unintended consequences of coronary artery bypass graft report cards. Circ 111(10):1257-1263. doi:10.1161/01.CIR.0000157729. 59754.09

209. Geschwind N, Peeters F, Jacobs N, Delespaul P, Derom C, Thiery E, van Os J, Wichers M (2010) Meeting risk with resilience: high daily life reward experience preserves mental health. Acta Psychiatr Scand 122(2):129-138. doi:10.1111/j.1600-0447.2009.01525.x

210. Chen E, Miller GE, Lachman ME, Gruenewald TL, Seeman TE (2012) Protective factors for adults from low-childhood socioeconomic circumstances: the benefits of shift-and-persist for allostatic load. Psychosom Med 74(2):178-186. doi:10.1097/PSY. 0b013e31824206fd

211. Ramey SL, Schafer P, DeClerque JL, Lanzi RG, Hobel C, Shalowitz M, Chinchilli V, Raju TN (2014) The preconception stress and resiliency pathways model: a multi-level framework on maternal, paternal, and child health disparities derived by community-based participatory research. Matern Child Health J. doi:10.1007/s10995-014-1581-1

212. Bonanno GA, Diminich ED (2013) Annual research review: positive adjustment to adversity - trajectories of minimal-impact resilience and emergent resilience. J Child Psychol Psychiatr 54(4):378401. doi:10.1111/jcpp. 12021

213. Cabib S, Campus P, Colelli V (2012) Learning to cope with stress: psychobiological mechanisms of stress resilience. Rev Neurosci 23(5-6):659-672. doi:10.1515/revneuro-2012-0080

214. Sapienza JK, Masten AS (2011) Understanding and promoting resilience in children and youth. Curr Opin Psychiatr 24(4):267273. doi:10.1097/YCO.0b013e32834776a8

215. Kristenson M, Eriksen HR, Sluiter JK, Starke D, Ursin H (2004) Psychobiological mechanisms of socioeconomic differences in health. Soc Sci Med 58(8):1511-1522. doi:10.1016/S02779536(03)00353-8 
216. Chiavarino C, Rabellino D, Ardito RB, Cavallero E, Palumbo L, Bergerone S, Gaita F, Bara BG (2012) Emotional coping is a better predictor of cardiac prognosis than depression and anxiety. J Psychosom Res 73(6):473-475. doi:10.1016/j.jpsychores.2012.10.002

217. LeDoux JE, Gorman JM (2001) A call to action: overcoming anxiety through active coping. Am J Psychiatr 158(12):1953-1955

218. Bowen MT, Hari Dass SA, Booth J, Suraev A, Vyas A, McGregor IS (2014) Active coping toward predatory stress is associated with lower corticosterone and progesterone plasma levels and decreased methylation in the medial amygdala vasopressin system. Horm Behav 66(3):561-566. doi:10.1016/j.yhbeh.2014.08.004

219. Pettinati HM, O'Brien CP, Dundon WD (2013) Current status of cooccurring mood and substance use disorders: a new therapeutic target. Am J Psychiatr 170(1):23-30. doi:10.1176/appi.ajp.2012.12010112

220. Clark TT, Salas-Wright CP, Vaughn MG, Whitfield KE (2014) Everyday discrimination and mood and substance use disorders: a latent profile analysis with African Americans and Caribbean Blacks. Addict Behav 40C:119-125. doi:10.1016/j.addbeh.2014.08.006

221. Franklin TB, Russig H, Weiss IC, Graff J, Linder N, Michalon A, Vizi S, Mansuy IM (2010) Epigenetic transmission of the impact of early stress across generations. Biol Psychiatr 68(5):408-415. doi: 10.1016/j.biopsych.2010.05.036

222. Ersche KD, Turton AJ, Chamberlain SR, Muller U, Bullmore ET, Robbins TW (2012) Cognitive dysfunction and anxious-impulsive personality traits are endophenotypes for drug dependence. Am J Psychiatr 169(9):926-936. doi:10.1176/appi.ajp.2012.11091421

223. Hing B, Gardner C, Potash JB (2014) Effects of negative stressors on DNA methylation in the brain: implications for mood and anxiety disorders. Am J Med Genet B Neuropsychiatr Genet 165(7):541-554. doi:10.1002/ajmg.b.32265

224. Chen BT, Yau HJ, Hatch C, Kusumoto-Yoshida I, Cho SL, Hopf FW, Bonci A (2013) Rescuing cocaine-induced prefrontal cortex hypoactivity prevents compulsive cocaine seeking. Nat 496(7445): 359-362. doi:10.1038/nature12024

225. Deroche-Gamonet V, Belin D, Piazza PV (2004) Evidence for addiction-like behavior in the rat. Sci 305(5686):1014-1017. doi: 10.1126/science. 1099020

226. Vanderschuren LJ, Everitt BJ (2004) Drug seeking becomes compulsive after prolonged cocaine self-administration. Sci 305(5686): 1017-1019. doi:10.1126/science.1098975 